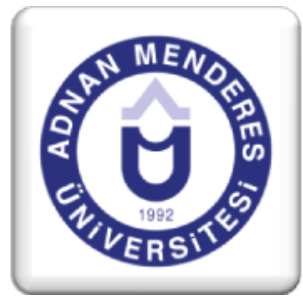

\title{
Yaş Meyve ve Sebze Sektörünün Dış Ticaret Yapısının Analizi: Türkiye ve BRIC Ülkeleri Örneği
}

Dilek ŞAHIN ${ }^{1}$

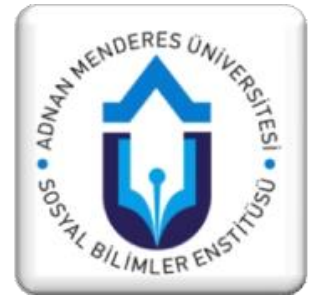

\section{ÖZET}

Bu çalışmanın esas amacı, Türkiye ve BRIC (Brezilya, Rusya, Hindistan, Çin) ülkelerinin yaş meyve ve sebze sektörü dış ticaret yapısını analiz etmektir. Çalışmada 2000-2014 dönemi esas alınmıştır. Çalışmada iki yöntem kullanılmıştır. İlk olarak yaş meyve ve sebze sektörünün endüstri-içi ticaret yapısı analiz edilmiştir. İkinci olarak yaş meyve ve sebze sektörünün rekabet gücü analiz edilmiştir. Sonuç olarak, Türkiye'de ve BRIC ülkelerinde yaş meyve ve sebze sektöründe endüstri içi ticaret seviyesinin düşük olduğu görülmüștür. Ayrıca, Türkiye'nin yaș meyve ve sebze sektöründe rekabet gücü yüksek bulunmuştur. BRIC ülkelerinde ise rekabet gücünün düşük olduğu görülmüş̧ür.

Anahtar Kelimeler: Yaş meyve ve sebze sektörü, dış ticaret, endüstri içi ticaret, açıklanmış karşılaştırmalı üstünlükler endeksi.

\section{Analysis of Foreign Trade Structure of Fresh Fruit and Vegetable Sector: The Case of Turkey and BRIC Countries}

\begin{abstract}
The main aim of this study is to analyzed the foreign trade structure of the fresh furit and vegetable sector in Turkey and BRIC (Brazil, Russia, India, China) countries. 2000-2014 period was used in this study. Two methods were used in this study. Firstly, intra-industry trade structure of the fresh fruit and vegetable sector was analyzed. Secondly, competitiveness of the fresh fruit and vegetable sector was analyzed. Consequently, it was seen that the level of intra-industry trade is low in the fresh fruit and vegetables sector in Turkey and BRIC countries. Also, it was found that Turkey's fresh fruit and vegetable sector competitiveness is high. It was found to be low competitiveness in the BRIC Countries.
\end{abstract}

Keywords: Fresh fruit and vegetable sector, foreign trade, intra industry trade, revealed comparative advantage.

\footnotetext{
${ }^{1}$ Cumhuriyet Üniversitesi, Turizm İşletmeciliği ve Otelcilik YO, Konaklama İşletmeciliği Bölümü, dilek58sahin@ Chotmail.com.
} 


\section{Giriş}

Tarım sektörü gelişmişlik seviyeleri ne olursa olsun tüm ülkelerin ekonomik hayatlarında önemli bir yere sahiptir. Tarım, çeşitli besin maddelerini üreten, bu maddeleri işleyerek besin maddelerini çeşitlendiren toplumların sağlığı ve kalkınması üzerinde önemli etkiye sahip olan sektördür. Tarım sektörü ülke nüfusunun yaşamını sürdürebilmesi, milli gelir ve istihdama katkısı, diğer sektörlere hammadde ve sermaye sağlaması, ihracata ve ithalata doğrudan ve dolaylı etkisi nedeniyle tüm dünyada vazgeçilmez bir sektör niteliğindedir.

Tarım sektörü genel ekonomik sistemin ayrılmaz bir parçasıdır. Tarım sektörü ekonomik gelişmeye, temel gıda maddelerinin üretimini sağlayarak, nüfusun önemli bir kısmını istihdam ederek, milli gelire ve ihracata destek olarak sanayi sektörüne ara malı sağlayarak ve talep yaratarak katkıda bulunmaktadır (Türkekul ve Abay, 2009: 34).Tarım sektörünün temel ihtiyaç maddelerinin üretilmesinde sahip olduğu rol nedeniyle bütün ülkeler, tarımsal ürünlerde özellikle tahıl, şeker, et, süt, bitkisel yă̆ gibi temel tarımsal ürünlerde kendine yeterli olma veya bu ürünleri büyük ölçüde yurtiçinden sağlama çabası içindedirler.

Yaş meyve ve sebze sektörü, tarım sektörü içerisindeki en önemli alt sektörlerden biridir. Yaş mey ve sebze sektörü, meyve ve sebzelerin tarımsal faaliyetlerle yetiştirilmesi ve yetiştirilen ürünlerin doğal bozunum süresinin tamamlanmasından önce ve üzerlerinde asli yapılarını değiştirici herhangi bir işlem yapılmadan nihai tüketicilere veya işleme tesislerine ulaştırılması faaliyetlerini içermektedir. Yaş meyve ve sebze sektörü, insanların temel ihtiyac1 olan bitkisel karbonhidrat, protein ve vitaminlere sahip besinlerin üretilmesi ve tüketime sunulması konusunda insanlık için hayati bir öneme sahiptir (DOAKA, 2015: 9). Yaş meyve ve sebze ekiminden ambalajlanmasına kadar, yarattığı istihdam ve getirdiği döviz getirisi nedeniyle katma değeri yüksek bir sektördür. Meyve ve sebze ihracatının artması için bol ve kaliteli üretim yapılması gerekmektedir. Yaş meyve ve sebze hassas ve kolay bozulabilen bir özelliği sahip olduğundan dolayı, nakliye konusu oldukça önemlidir.

FAO verilerine göre, 2012 yılında dünyada 636 milyon ton yaş meyve üretimi ve 1.1 milyar ton yaş sebze üretimi yapılmıştır. Son beş yılda küresel yaş meyve üretiminde yaklaşık $\% 8$ 'lik artış gözlenirken; küresel yaş sebze üretimde ise yaklaşık \%11 artış olmuştur. Toplam yaş meyve 636 milyon ton olup, yaklaşık 102 milyon ton üretim miktarı ile muz dünyada en fazla yetiştirilen meyve türüdür. Muzu 76,3 milyon ton ile elma; 68,2 milyon ton ile portakal, 42,1 milyon ton ile mango takip etmektedir. 2012 y1lında dünyada 57,2 milyon hektar alanda yaş sebze üretimi yapılmıştır. Söz konusu alanda yetiştirilen toplam yaş sebze 1,1 milyar ton olup domates yaklaşık 162 milyon tonluk üretim ile dünyada en fazla yetiştirilen yaş sebze olmuştur. Domatesi sırasılyla 105 milyon ton ile karpuz; 83 milyon ton ile kuru soğan; 70 milyon ton ile lahana; 65 milyon ton ile salatalık takip etmektedir. 137 milyon ton ile Çin dünyada en çok meyve üreten ülkeler arasında ilk sırada yer almaktadır. Çin'i sırasıly 71 milyon ton üretim ile Hindistan; 38 milyon ton ile Brezilya; 26 milyon ton ile ABD; 17 milyon ton üretim ile Endonezya; 13 milyon ton ile İtalya takip etmektedir. Türkiye 14 milyon ton ile 14.sırada yer almaktadır. Benzer şekilde Çin 573 milyon ton üretim ile sebze üretiminde de ilk sırada yer almaktadır. Çin'i sırasıyla 109 milyon ton ile Hindistan; 35 milyon ton ile ABD; 27 milyon ton ile Türkiye takip etmektedir (Ekonomi Bakanlığı, 2014: 1-2; ŞUTSO, 2013: 18-23).

2012 y1lı itibariyle dünyada toplam yaş meyve ihracatı 61,8 milyar dolar seviyesinde gerçekleşmiştir. Bu ihracatta İspanya 7,4 milyar dolar ile ilk sırada yer alırken; 6,2 milyar dolar ile ABD; 4 milyar dolar ile Şili; 3,8 milyar dolar ile Hollanda ve 3,3 milyar dolar ile İtalya takip etmiştir. Türkiye ise 1,7 milyar dolarlık ihracat hacmi ile dünya yaş meyve ihracatında \%2,7'lik paya sahiptir. Benzer şekilde 2012 y1lında dünya yaş sebze ihracatı 31,7 
milyar dolar olmuştur. Hollanda 5,2 milyar dolarlık ihracatı ile dünya ihracatında \%17,1'lik pay almış, bu ülkeyi 4,2 milyar dolar ile İspanya; 3,9 milyar dolar ile Meksika; 2,9 milyar dolar ile Çin; 2,1 milyar dolar ile ABD takip etmiştir. Türkiye ise 611 milyon dolarlık ihracat hacmi ile yaş sebze sektörü ihracatında \%1,9'luk pay almıştır (Ekonomi Bakanlığı, 2014: 4$6)$.

Türkiye'nin ve BRIC (Brezilya, Rusya, Hindistan, Çin) ülkelerinin yaş meyve ve sebze sektörünün dış ticaret yapısının analiz edildiği bu çalışmada ilk olarak sektörün endüstri içi ticaret yapısına ardından rekabet gücüne bakılmıştır. Endüstri içi ticaretin ölçümünde literatürde sıklıkla kullanılan Grubel-Lloyd Endeksi (GL) kullanılmıştır. Rekabet gücü ölçümünde ise Açıklanmış Karşılaştırmalı Üstünlükler Endeksi (AKÜ) kullanılmıştır. Çalışmada 2000-2014 dönemleri arası analiz edilmiştir. SITC (Uluslararası Standart Ticaret Sınıflandırması) Rev.3 dört haneli sınıflandırma düzeyi kullanılmıştır. Analiz sonuçları, Türkiye'nin yaş meyve ve sebze sektöründe endüstri içi ticaret seviyesinin düşük olduğunu göstermiştir. Benzer şekilde BRIC ülkelerinde de yaş meyve ve sebze sektöründe endüstri içi ticaret seviyesi düşüktür. Rekabet gücü analizinde ise; Türkiye'nin yaş meyve ve sebze sektöründe rekabet gücünün yüksek olduğu görülmüştür. BRIC ülkelerinin ise yaş meyve ve sebze sektöründe rekabet gücünün düşük olduğu sonucuna ulaşılmıştır.

\section{Literatür Taraması}

Literatürde endüstri içi ticaretin ölçümüne ilişkin çalışmalardan bazılarını aşağıdaki gibi özetlemek mümkündür:

Hellvin (1996), Çin ile OECD ülkeleri arasındaki endüstri içi ticaret (EİT) düzeyi 1980-1992 yılları için hesaplanmıştır. Çalışmada SITC Rev.3 sınıflandırması kullanılmıştır. Çalışma sonucunda Çin ile OECD ülkeleri arasındaki EİT düzeyinin arttı̆̆ı ve EİT'nin önemli kısmının dikey EİT şeklinde gerçekleştiği görülmüştür. Çin faktör donatımı farklılığından kaynaklı olarak düşük kaliteli malların ihracatını yaparken OECD ülkelerinden yüksek kaliteli malların ithalatını gerçekleştirmektedir. Çin'de EİT'nin artış nedenleri arasında hızlı ekonomik büyüme ve doğrudan yabancı sermaye yatırımlarındaki artış gelmektedir. Çalışmada tarifelerin Çin ile OECD ülkeleri arasındaki endüstri-içi ticaretin büyümesi önündeki en önemli engel olduğu görülmüştür.

$H u$ ve Ma (1999), Çin'in endüstri-içi ticaretindeki artış ölçülmüş, Çin ve 45 ana ticari partneri arasındaki dikey ve yatay endüstri-içi ticaretin belirleyicileriyle ilgili çeşitli ampirik testler yapılmıştır. 1970'lerin sonlarından itibaren Çin hükümetinin açık ekonomi politikasını takip ettiği ve 1979-1996 yılları arasında Çin'de uluslararası ticaretin arttığı ifade edilmiştir. Çalışmada endüstri-içi ticaretin sadece Çin ve benzer faktör donanımına sahip gelişmekte olan ülkeler arasında değil aynı zamanda Çin ve gelişmiş ülkeler arasında da gerçekleştiği sonucuna ulaşı1mıştır.

Çakmak (2006), Türkiye ile Almanya, İtalya, Fransa ve İngiltere arasında imalat endüstrisi dış ticaretinde EİT'nin yapısını ve önemini tespit etmek amacıyla 1991-2004 döneminde SITC Rev.3 üç basamaklı ürün grupları verileri ve standart G-L endeksi kullanılarak bir araştırma yapılmıştır. Buna göre, ilgili dönemde Türkiye ile dört ülke arasındaki EİT oranlarını temel alan sıralamanın zamanla çok değiştiği, söz konusu dönemin başlarında Türkiye ile imalat endüstrisi EİT düzeyi en yüksek ülkeler sirasılyla İngiltere, İtalya, Almanya ve Fransa iken, dönemin sonlarına doğru bu sıralama Fransa, İtalya, Almanya ve İngiltere biçiminde olduğu ifade edilmektedir.

Deviren ve Karataş (2007), Türkiye ve Çin arasında 1995-2005 döneminde SITC Rev.3'e göre, üç hane düzeyinde gerçekleşen endüstri-içi ticaret endeksin 0.50 ve üstü değer aldığı 
ürünler gerek SITC temel ürün gruplarına gerekse teknolojik yapıya göre sinıflandırılarak incelemiştir. Her iki sınıflandırma da Grubel-Lloyd'un ağırlıklı ortalaması kullanılmıştır.1995-2005 yılları arasında Türkiye'nin Çin ile yaptığı endüstri-içi ticaret düzeyi SITC ürün gruplarına göre 0-4 ilksel ürünler,5-8 sınai ürünleri, 0-8 tüm ürünlere ilişkin olarak hem Grubel-Lloyd'un ağırlıklı ortalaması hem de düzeltilmiş endeksten yararlanılarak hesaplanmıştır. Hesaplamalara göre ilksel ürünler, sınai ürünleri ve tüm ürünlere ilişkin endüstri-içi ticaretin endeks değerinin 0.50'nin altında kalmaktadır. $\mathrm{Bu}$ bağlamda, Türkiye'nin Çin ile yaptığı dış ticaretin endüstriler-arası ticaret yapısı gösterdiği sonucuna ulaşı1mıştır.

Özkaya (2010), Türk tekstil sektöründeki endüstri-içi ticaretle ilgili gelişmeler 1989-2009 yılları için Grubel-Lloyd endeksi kullanılarak ortaya konulmuştur. Daha sonra yatay endüstri-içi ticaret ve dikey endüstri-içi ticaret ayrımı dikkate alınmış ve endüstri-içi ticareti etkileyen faktörleri tespit etmek amacıyla ülkeye ve sektöre özgü belirleyicileri esas alan regresyon analizi yapılmıştır. Bu analize göre kişi başına düşen gelir ve ölçek ekonomileri tekstil sektöründe endüstri-içi ticaret düzeyini olumlu etkilerken, doğrudan yabancı yatırımların olumsuz etkilediği sonucuna ulaşılmıştır.

Han ve Lee (2012), Çin ve Kore arasındaki toplam ticaretin ne kadarın dikey endüstri-içi ticaret şeklinde gerçekleştiği hesaplanmıştır. SITC Rev.5 ürün gruplandırması kullanılmıştır. Çalışmada, Çin ve Kore arasında 1990 yılından itibaren gerçekleştirilen ticaretin yaklaşık \%50'sinin endüstri-içi ticaret şeklinde gerçekleștiği görülmüştür. Yapılan analizler endüstriiçi ticaretin çoğunluğunun dikey endüstri-içi ticaret şeklinde gerçekleştiğini göstermiştir. Ancak bu durumun bazı sektörlerde değiştiği sonucuna ulaşılmıştır. Kimya sanayinde 2000'li yıllardan itibaren yatay endüstri-içi ticaret artarken dikey endüstri-içi ticaret azalmaktadır. Diğer yandan tekstil, fabrikasyon metal ve makine sanayi ve elektronik sanayi de dikey endüstri-içi ticaret artarken yatay endüstri-içi ticaret azalmaktadır.

$L i$ vd., (2015), Çin ve Güney Kore arasındaki imalat sanayi ürünlerinin ticaretinin yönü belirlenmeye çalışılmıştır. İmalat sanayi ürünlerinde endüstri-içi ticaret seviyesinin ölçümü için statik ölçüm (G-L endeksi) ve dinamik ölçüm (MEIT) hesaplanmıştır. Çalışmada sonuç olarak Çin ve Güney Kore arasında imalat sanayi ürünlerinde endüstri-içi ticaret seviyesinin arttığ 1 görülmüştür. Fakat bu artışın sermaye ve teknoloji yoğun ürünlerde daha yüksek olduğu görülmüştür. Güney Kore'den Çin'e yapılan yabanc1 sermaye yatırımları, Güney Kore ve Çin'in piyasa büyüklüğü, iki ülkenin kişi başına düşen GSYH'sı gibi faktörlerin Çin ve Güney Kore arasındaki endüstri-içi ticaretin seviyesini farklı derecede etkilediği sonucuna ulaşı1mıştır.

Literatürde rekabet gücünün ölçümüne ilişkin yapılan çalışmalardan bazılarını aşağıdaki gibi özetlemek mümkündür:

Serin ve Civan (2008), Türkiye'nin domates, zeytinyağ 1 ve meyve suyu sanayisinin $\mathrm{AB}$ pazarında karşılaştırmalı üstünlüğü 1995-2005 dönemi itibariyle ele alınmıştır. Yöntem olarak, Açıklanmış Karşılaştırmalı Üstünlükler Endeksi ve Karşılaştırmalı İhracat Performans Endeksi kullanılmıştır. Sonuç olarak, Türkiye'nin AB pazarında meyve suyu ve zeytinyağı piyasalarında karşılaştırmalı üstünlüğün yüksek bulunduğu; domates pazarında ise karşılaştırmalı üstünlüğün düşük olduğu görülmüsstür.

Bakhshinejad ve Zahed (2012), Açıklanmış Karşılaştırmalı Üstünlükler Endeksi kullanılarak İran'ın seçilmiş tarımsal ürünlerde rekabet gücü analiz edilmiştir. Çalışmada analizler 2007 yılı için yapılmış ve ceviz, badem, findık, elma ve portakal ürünlerinde rekabet gücü hesaplanmıştır. Sonuç olarak, İran'ın bu ürünlerde rekabet gücüne sahip olmadığı görülmüştür. Çalışmada ayrıca İran'ın rekabet gücünün artırılması için tarımsal verimliliğin 
artırılması, yerli teknolojinin geliştirilmesi ve iş yapma maliyetinin azaltılması gibi öneriler sunulmuştur.

Hassan (2013), Pakistan'ın tarımsal ürünler ticaretinde (pirinç, balık ve balık ürünleri, sebze ve meyve, et ve et ürünleri) rekabet gücü Asya ülkeleri karşısında analiz edilmiştir. Çalışmada Açıklanmış Karşılaştırmalı Üstünlükler Endeksi kullanılmıştır. Çalışmada 20012010 dönemi ele alınmıştır. Sonuç olarak ele alınan ürünlerin tamamında rekabet gücünün arttı̆̆ 1 görülmüştür.

Ishchukova ve Smutha (2013), Rusya'nın 1998-2010 dönemleri arasında tarımsal ürün ve gıda maddeleri sektöründe rekabet gücü analiz edilmiştir. Çalışmada karşılaştırmalı üstünlükler; Balassa Endeksi, Vollrath Endeksi ve Lafay Endeksi kullanılarak ölçülmüştür. Balassa Endeksi ele alınan dönem boyunca istikrarlı karşılaştırmalı üstünlüğe sahip ürünler arasında hububat, yağlı tohumlar, bitkisel yağlar ve çikolata olduğunu göstermiştir. Vollrath Endeksi ele alınan dönemlerde karşılaştırmalı üstünlüğün ürün bazında arttı̆̆ını göstermiştir. Son olarak Lafay Endeksi ise, Rusya'nın Bağımsız Devletler Topluluğu ve Asya ülkeleri ile olan ilişkilerinde coğrafik konum ve iyi ticari ilişkiler bakımından karşılaştırmalı üstünlüğe sahip olduğunu göstermiştir.

Erkan vd., (2015), Türkiye'nin dünya piyasalarında sebze ihracatında karşılaştırmalı üstünlüğü analiz edilmiştir. Çalışmada 1993-2012 yılları arasında analiz edilmiş ve SITC Rev.3 dört haneli sınıflandırma kullanılmıştır. Sonuç olarak, Türkiye'nin sebze ve alt grupları ihracatında küresel piyasalarda karşılaştırmalı üstünlüğe sahip olduğu görülmüştür. Bununla birlikte, sebze alt gruplarının büyük çoğunluğunun ihracatında karşılaştırmalı üstünlük olmasına rağmen son yıllardaki üstünlügün nispi anlamda azaldığı sonucuna ulaşılmıştır.

\section{Veri Seti ve Yöntem}

Yaş meyve ve sebze sektörünün diş ticaret yapısının analiz edildiği bu çalışmada iki uygulama yapılmıştır. İlk uygulama endüstri-içi ticaretin analizidir. İkinci uygulama ise rekabet gücünün ölçümüne yöneliktir. Çalışmada kullanılan dış ticaret verilerine (ithalatihracat) Birleşmiş Milletlerin (UN) Comtrade veri tabanından ulaşılmıştır. Çalışma 20002014 dönemini kapsamaktadır.

Çalışmada kullanılan yaş meyve ve sebze sektörü SITC Rev.3 dört haneli sınıflandırmaya göre şu şekildedir:

Yaş meyve sektörü: 0571 (Portakal ve Mandalina (taze/kurutulmuş)), 0572 (Greyfurt, pomelo, limon ve diğer turunçgiller), 0573 (Muz), 0574 (Elma), 0575 (Üzüm), 0576 (incir (taze / kurutulmuş), 0577 (Çeşitli cevizler ve diğer kabuklu meyveler (taze/kurutulmuş)), 0579 (Kavun, karpuz, papaya, elma, armut, ayva ve diğer meyveler (taze)).

Yaş sebze sektörü: 0541 (Patates (taze-soğutulmuş), 0542 (Baklagiller), 0544 (domates (taze/ dondurulmuş), 0545 (Taze ve Soğutulmuş Sebzeler), 0546 (Pişirilmiş ve Dondurulmuş Sebzeler), 0547 (Sebze ve sebze karışımları (geçici konserve edilmiş)), 0548 (Manyot, şerbetçi otu, salep, ararot, keçiboynuzu, seker pancarı-kamış1 vs.)).

Çalışmada kullanılan yöntemleri şu şekilde özetlemek mümkündür:

Endüstri-içi ticaretin ölçümünde literatürde sıklıkla kullanılan Grubel-Lloyd yöntemi kullanılmıştır. Bu yöntemde $X_{i}$ ihracat değeri, $M_{i}$ ithalat değerini göstermek üzere endüstriiçi ticaret aşağıdaki gibi ifade edilmektedir (Grubel ve Lloyd, 1975: 21): 


$$
B i=\frac{\sum_{i}^{n}[(X i+M i)-(X i-M i)]}{\sum_{i}^{n}(X i+M i)} \text { veya } B i=1-\frac{|X i-M i|}{X i+M i}
$$

(1)

Endeks 0 ile 1 arasında değer almakla birlikte, eğer ülke söz konusu malı yalnızca ihraç ya da ithal ediyorsa (endüstri-içi ticaret yoksa) endeks 0 olmaktadır. Eğer aynı malın ithalatı ve ihracatı birbirine eşit ise endeks değeri 1 olmakta ve bu durum endüstri-içi ticaret seviyesinin maksimum olduğunu göstermektedir.

Endüstri içi ticaret, belirli bir endüstri kapsamında bulunan, birbirinden farklılaştırılmış yapıdaki ürünlerin eşzamanlı olarak ihraç ve ithal edilmesi durumudur. Endüstri içi ticaret faktör donanımı benzer olan ülkeler arasında daha yüksek düzeydedir. Esasında endüstri içi ticarette dış ticaretten sağlanan kazanç, tüketicilere sağlanan tercih çeşitliliği ve üretimde gerçekleşen ölçek ekonomilerinden kaynaklanmaktadır.

Ülkeler arasında gerçekleşen ticarette endüstri içi ticaretin payının yükselmesinin bazı nedenleri bulunmaktadır. Ülkelerin kişi başına gelir farklılığı ne kadar düşük seviye de ise, endüstri-içi ticaretin toplam ticaret içindeki payı o kadar fazla olmaktadır. Yine ülkeler arasındaki kişi başına düşen gelir seviyesi artıkça endüstri-içi ticaretin payı da artacaktır. Ülkelerin piyasa büyüklükleri birbirine yaklaştıkça endüstri-içi ticaret düzeyi artmaktadır. Ticari serbestleşme endüstri-içi ticareti kolaylaştırarak ticaretin yayılmasını kolaylaştırmaktadır. Özellikle serbestleşme ve küreselleşmenin etkisiyle ülkeler ve bölgeler arasında mal ve hizmet akımlarının hızla gelişmesi firmaların üretim süreçlerini maliyet avantajı sağlayan coğrafi alanlara kaydırmasına ve böylelikle endüstri-içi ticaretin artmasına yol açmaktadır.

Endüstriler arası ticaret ise, birbirinden tamamen farklı yapıdaki ürünlerin karşılaştırmalı üstünlük veya karşılaştırmalı dezavantaj durumuna göre ihraç ve ithal edilmesidir. Bir ülkenin endüstriler arası ticaret durumu o ülkenin karşılaştırmalı üstünlük yapısına bağlı olarak belirlenmektedir. Endüstriler arası ticarette diş ticaretten sağlanan kazanç uzmanlaşma ve ürünlerin mübadelesinden kaynaklanmaktadır.

İkinci uygulama olan rekabet gücü ölçümünde ise; Açıklanmış Karşılaştırmalı Üstünlükler Endeksi kullanılmıştır. Bu yöntemi aşağıdaki gibi özetlemek mümkündür:

Açıklanmış Karşılaştırmalı Üstünlükler Endeksi, Balassa (1965) tarafından geliştirilmiştir. $\mathrm{Bu}$ endeks bir ülkenin belirli bir sektör ihracatının toplam ihracatına oranının, aynı sektörün dünya ihracatının dünya toplam ihracatına oranı olarak tanımlanmaktadır (Erkan, 2012: 198). Endeks(AKÜ) şu şekilde formüle edilmektedir.

$$
A K U_{i j}=\left[\left(\frac{X_{i j}}{X_{i}}\right) \div\left(\frac{X_{j w}}{X_{w}}\right)\right]
$$

(2) nolu Eşitlikte, i ülkeyi, $\mathrm{j}$ ürünü (sektörü), $\mathrm{X}$ ihracat1, $\mathrm{M}$ ithalat1 göstermekle birlikte; eşitliğin pay kısmı ürünün (sektörün) ulusal ihracattaki payını, payda kısmı ise ürünün 
(sektörün) dünya toplam ihracatındaki payını göstermektedir. Endeks değeri 0 ile $\infty$ arasında değer almaktadır. Eğer, endeks değeri 1'den büyükse (AKÜ>1) ilgili ülke ele alınan ürünün (sektörün) ihracatında karşılaştırmalı üstünlüğe sahiptir (rekabet gücü yüksek). Endeks değeri 1'den küçükse $(A K U ̈<1)$ ilgili ülke ele alınan ürünün (sektörün) ihracatında karşılaştırmalı dezavantaja sahiptir (rekabet gücü düşük).

\section{Bulgular ve Değerlendirmeler}

Bu başlık altında öncelikle Türkiye ve BRIC ülkelerinin yaş meyve ve sebze sektöründe dış ticaret yapısı analiz edilmiştir. Bu kapsamda öncelikle yaş meyve ve sebze sektöründe endüstri içi ticaret seviyesi belirlenmeye çalışılmıştır. Ardından yaş meyve ve sebze sektöründe rekabet gücü analiz edilerek elde edilen bulgular yorumlanmıştır.

\subsection{Türkiye'nin Yaş Meyve ve Sebze Sektörü Dış Ticaret Yapısının Analizi}

Tablo 1'de Türkiye'nin yaş meyve ve sebze sektöründe endüstri içi ticaret seviyesi gösterilmiştir. Literatürde, Grubel-Lloyd Endeksinin (GL) 0.50'den yüksek olması durumu endüstri içi ticaretin varlığını ifade etmektedir. Bu bağlamda tablo 1 değerlendirildiğinde, Türkiye'nin yaş meyve ve sebze sektöründe endüstri içi ticaret seviyesinin yüksek olduğu sektörler arasında; 0541 (Patates (taze-soğutulmuş), 0542 (Baklagiller), 0547 (Sebze ve sebze karışımları (geçici konserve edilmiş)) ve 0548 (Manyot, şerbetçi otu, salep, ararot, keçiboynuzu, seker pancarı-kamışı vs.)) bulunmaktadır. Endüstri içi ticaretin yüksek düzeyde olması belirli bir karşılaştırmalı üstünlük durumunun ortaya çıkmadığını göstermektedir.

Ele alınan diğer sektörlerde ise endüstri içi ticaret seviyesinin düşük olduğu görülmektedir. Genel itibariyle değerlendirildiğinde; Türkiye'nin yaş meyve ve sebze sektöründe endüstri içi ticaret seviyesinin düşük olduğu diğer bir ifadeyle gerçekleşen ticaretin endüstriler arası ticaret şeklinde olduğu görülmektedir. Esasında endüstriler arası ticaret, birbirinden tamamen farklı yapıdaki ürünlerin karşılaştırmalı üstünlük veya karşılaştırmalı dezavantaj durumuna göre ihraç ve ithal edilmesi durumudur. 
Tablo 1.Yaş Meyve ve Sebze Sektöründe Endüstri içi Ticaretin Ölçümü

\begin{tabular}{|c|c|c|c|c|c|c|c|c|c|c|c|c|c|c|c|}
\hline Sektör & $\mathbf{2 0 0 0}$ & $\mathbf{2 0 0 1}$ & $\mathbf{2 0 0 2}$ & $\mathbf{2 0 0 3}$ & $\mathbf{2 0 0 4}$ & $\mathbf{2 0 0 5}$ & $\mathbf{2 0 0 6}$ & $\mathbf{2 0 0 7}$ & $\mathbf{2 0 0 8}$ & $\mathbf{2 0 0 9}$ & $\mathbf{2 0 1 0}$ & $\mathbf{2 0 1 1}$ & $\mathbf{2 0 1 2}$ & $\mathbf{2 0 1 3}$ & $\mathbf{2 0 1 4}$ \\
\hline $\mathbf{0 5 7 1}$ & 0,00 & 0,00 & 0,06 & 0,08 & 0,08 & 0,11 & 0,05 & 0,09 & 0,06 & 0,04 & 0,04 & 0,05 & 0,05 & 0,05 & 0,04 \\
\hline $\mathbf{0 5 7 2}$ & 0,00 & 0,00 & 0,03 & 0,04 & 0,03 & 0,03 & 0,01 & 0,01 & 0,02 & 0,01 & 0,01 & 0,00 & 0,01 & 0,01 & 0,01 \\
\hline $\mathbf{0 5 7 3}$ & 0,00 & 0,01 & 0,00 & 0,00 & 0,01 & 0,00 & 0,00 & 0,00 & 0,00 & 0,00 & 0,00 & 0,00 & 0,00 & na & 0,00 \\
\hline $\mathbf{0 5 7 4}$ & 0,39 & 0,14 & 0,34 & 0,23 & 0,26 & 0,40 & 0,46 & $0,89^{*}$ & 0,37 & 0,30 & 0,14 & 0,25 & 0,19 & 0,08 & 0,12 \\
\hline $\mathbf{0 5 7 5}$ & 0,01 & 0,01 & 0,01 & 0,01 & 0,01 & 0,01 & 0,01 & 0,01 & 0,01 & 0,01 & 0,01 & 0,01 & 0,01 & 0,01 & 0,01 \\
\hline $\mathbf{0 5 7 6}$ & 0,05 & 0,06 & 0,04 & 0,03 & 0,02 & 0,03 & 0,04 & 0,03 & 0,07 & 0,07 & 0,03 & 0,04 & 0,04 & 0,02 & 0,02 \\
\hline $\mathbf{0 5 7 7}$ & 0,04 & 0,02 & 0,10 & 0,09 & 0,08 & 0,08 & 0,16 & 0,19 & 0,30 & 0,34 & 0,27 & 0,28 & 0,36 & 0,31 & 0,26 \\
\hline $\mathbf{0 5 7 9}$ & 0,05 & 0,04 & 0,05 & 0,03 & 0,04 & 0,06 & 0,05 & 0,07 & 0,06 & 0,07 & 0,07 & 0,11 & 0,09 & 0,09 & 0,10 \\
\hline $\mathbf{0 5 4 1}$ & 0,31 & 0,11 & $0,58^{*}$ & 0,47 & $0,57^{*}$ & $0,90^{*}$ & $0,74^{*}$ & $0,62^{*}$ & $0,79^{*}$ & $0,83^{*}$ & $0,72^{*}$ & $0,89^{*}$ & $0,78^{*}$ & 0,30 & 0,33 \\
\hline $\mathbf{0 5 4 2}$ & $0,87^{*}$ & 0,49 & 0,48 & 0,13 & 0,16 & $0,54^{*}$ & 0,42 & $0,58^{*}$ & $0,71^{*}$ & $0,86^{*}$ & $0,96^{*}$ & $0,94^{*}$ & $0,98^{*}$ & $0,89^{*}$ & $0,77^{*}$ \\
\hline $\mathbf{0 5 4 4}$ & 0,00 & 0,00 & 0,00 & 0,00 & 0,00 & 0,00 & na & 0,00 & 0,00 & 0,00 & 0,00 & 0,00 & 0,00 & 0,00 & 0,00 \\
\hline $\mathbf{0 5 4 5}$ & 0,01 & 0,00 & 0,02 & 0,03 & 0,01 & 0,00 & 0,02 & 0,05 & 0,09 & 0,03 & 0,05 & 0,11 & 0,06 & 0,08 & 0,06 \\
\hline $\mathbf{0 5 4 6}$ & 0,03 & 0,02 & 0,06 & 0,04 & 0,11 & 0,10 & 0,05 & 0,11 & 0,29 & 0,32 & 0,50 & $0,65^{*}$ & 0,50 & 0,36 & 0,41 \\
\hline $\mathbf{0 5 4 7}$ & 0,15 & 0,39 & $0,54^{*}$ & 0,43 & 0,49 & $0,61^{*}$ & $0,55^{*}$ & $0,68^{*}$ & $0,98^{*}$ & $0,72^{*}$ & $0,79^{*}$ & $0,97^{*}$ & $0,77^{*}$ & $0,67^{*}$ & 0,48 \\
\hline $\mathbf{0 5 4 8}$ & $0,76^{*}$ & 0,38 & $0,66^{*}$ & $0,59^{*}$ & $0,54^{*}$ & 0,42 & 0,49 & 0,42 & $0,73^{*}$ & 0,36 & 0,33 & 0,38 & $0,59^{*}$ & 0,47 & $0,62^{*}$ \\
\hline
\end{tabular}

Kaynak: UN Comtrade veri tabanından yola çıkılarak tarafımızca hesaplanarak düzenlenmiştir. Not: Literatürde endeks değeri 0,50 'den yüksek ise endüstri-içi ticaretin olduğu kabul edilmektedir. * endüstri-içi ticaretin olduğunu göstermektedir.

Tablo 2'de Açıklanmış Karşılaştırmalı Üstünlükler Endeks (AKÜ) değerleri yer almaktadır. Türkiye'nin yaş meyve ve sebze sektöründe rekabet gücünün yüksek olduğu sektörler arasında; 0571 (Portakal ve Mandalina (taze/kurutulmuş)), 0572 (Greyfurt, pomelo, limon ve diğer turunçgiller), 0575 (Üzüm), 0576 (incir (taze / kurutulmuş), 0577 (Çeşitli cevizler ve diğer kabuklu meyveler (taze / kurutulmuş)), 0579 (Kavun, karpuz, papaya, elma, armut, ayva ve diğer meyveler (taze)), 0542 (Baklagiller), 0544 (domates (taze/ dondurulmuş), 0545 (Taze ve Soğutulmuş Sebzeler), 0546 (Pişirilmiş ve Dondurulmuş Sebzeler) ve 0547 (Sebze ve sebze karışımları (geçici konserve edilmiş)) bulunmaktadır. Bu sektörlerde AKÜ endeks değerlerinin 1'den büyük olduğu görülmektedir. 0541(Patates (taze-soğutulmuş) sektöründe Türkiye'nin bazı yıllarda endeks değerinin 1'den büyük olduğu yani rekabet gücünün yüksek olduğu görülmektedir. Bazı yıllarda ise rekabet gücünün düşük olduğu dikkat çekmektedir. Ancak genel itibariyle bu sektörde rekabet gücü düşüktür. Benzer durum 0548 (Manyot, şerbetçi otu, salep, ararot, keçiboynuzu, seker pancar1-kamışı vs.)) sektöründe de söz konusudur. Bu sektörde 2007 y1lına kadar rekabet gücünün yüksek olduğu ancak sonraki yıllarda rekabet gücünün düştügü görülmektedir. Genel itibariyle değerlendirildiğinde Türkiye'nin yaş meyve ve sebze sektöründe ele alınan dönemler itibariyle rekabet gücünün yüksek olduğu sonucuna ulaşılmaktadır. 
Tablo 2. Yaş Meyve ve Sebze Sektöründe Rekabet Gücünün Ölçümü

\begin{tabular}{|c|c|c|c|c|c|c|c|c|c|c|c|c|c|c|c|}
\hline Sektör & $\mathbf{2 0 0 0}$ & $\mathbf{2 0 0 1}$ & $\mathbf{2 0 0 2}$ & $\mathbf{2 0 0 3}$ & $\mathbf{2 0 0 4}$ & $\mathbf{2 0 0 5}$ & $\mathbf{2 0 0 6}$ & $\mathbf{2 0 0 7}$ & $\mathbf{2 0 0 8}$ & $\mathbf{2 0 0 9}$ & $\mathbf{2 0 1 0}$ & $\mathbf{2 0 1 1}$ & $\mathbf{2 0 1 2}$ & $\mathbf{2 0 1 3}$ & $\mathbf{2 0 1 4}$ \\
\hline $\mathbf{0 5 7 1}$ & 5,74 & 6,70 & 6,66 & 5,16 & 4,28 & 5,02 & 6,26 & 5,04 & 4,68 & 6,62 & 7,00 & 8,84 & 6,76 & 6,78 & 6,93 \\
\hline $\mathbf{0 5 7 2}$ & 17,4 & 14,7 & 16,0 & 11,5 & 12,7 & 16,4 & 16,1 & 13,9 & 11,2 & 17 & 18,5 & 20,6 & 14,5 & 13,7 & 11,4 \\
\hline $\mathbf{0 5 7 3}$ & 0,00 & 0,00 & 0,00 & 0,00 & 0,00 & 0,00 & 0,00 & 0,00 & 0,00 & 0,00 & 0,00 & 0,00 & 0,00 & na & 0,00 \\
\hline $\mathbf{0 5 7 4}$ & 0,51 & 0,59 & 0,38 & 0,46 & 0,36 & 0,42 & 0,32 & 0,12 & 0,23 & 0,49 & 0,66 & 0,67 & 0,46 & 0,72 & 0,62 \\
\hline $\mathbf{0 5 7 5}$ & 16,6 & 12,3 & 10,9 & 9,73 & 10,5 & 9,02 & 10 & 9,74 & 8,55 & 9,83 & 10,3 & 10,3 & 9,12 & 8,66 & 8,16 \\
\hline $\mathbf{0 5 7 6}$ & 122 & 109 & 100 & 85,8 & 77,9 & 76,6 & 76,6 & 79,4 & 65,7 & 67,4 & 71,8 & 69,9 & 66 & 71,6 & 70,9 \\
\hline $\mathbf{0 5 7 7}$ & 19 & 23,4 & 15,5 & 12,4 & 15,1 & 17,6 & 13,7 & 12,9 & 9,92 & 9,25 & 9,67 & 8,80 & 7,99 & 7,40 & 7,77 \\
\hline $\mathbf{0 5 7 9}$ & 4,39 & 3,81 & 4,01 & 4,14 & 4,24 & 3,29 & 3,50 & 3,26 & 3,27 & 3,28 & 3,92 & 3,43 & 2,78 & 2,94 & 2,83 \\
\hline $\mathbf{0 5 4 1}$ & 4,25 & 1,7 & 0,25 & 1,39 & 0,96 & 0,46 & 0,39 & 1,41 & 0,31 & 0,22 & 0,35 & 0,49 & 0,35 & 1,09 & 0,12 \\
\hline $\mathbf{0 5 4 2}$ & 9,52 & 14 & 8,10 & 11,8 & 8,48 & 6,58 & 9,27 & 5,23 & 3,56 & 5,10 & 4,67 & 4,33 & 2,91 & 2,95 & 3,09 \\
\hline $\mathbf{0 5 4 4}$ & 2,90 & 3,18 & 3,59 & 3,19 & 3,50 & 3,99 & 4,29 & 5,64 & 6,29 & 6,91 & 7,64 & 6,66 & 5,68 & 5,29 & 5,31 \\
\hline $\mathbf{0 5 4 5}$ & 1,23 & 1,13 & 1,11 & 1,08 & 0,94 & 1,06 & 1,17 & 1,16 & 1,17 & 1,12 & 1,13 & 1,12 & 1,06 & 1,03 & 1,10 \\
\hline $\mathbf{0 5 4 6}$ & 2,38 & 2,20 & 1,95 & 2,11 & 2,42 & 1,78 & 1,96 & 1,88 & 1,50 & 1,35 & 1,15 & 1,20 & 0,81 & 1,00 & 0,98 \\
\hline $\mathbf{0 5 4 7}$ & 7,14 & 5,92 & 5,65 & 3,83 & 2,83 & 2,97 & 3,18 & 3,15 & 2,85 & 3,17 & 3,23 & 2,40 & 1,80 & 1,79 & 1,16 \\
\hline $\mathbf{0 5 4 8}$ & 2,84 & 2,81 & 2,23 & 1,82 & 1,42 & 1,62 & 1,47 & 1,08 & 0,89 & 0,94 & 0,94 & 0,93 & 0,80 & 0,94 & 0,57 \\
\hline
\end{tabular}

Kaynak: UN Comtrade veri tabanından yola çıkılarak tarafımızca hesaplanarak düzenlenmiştir. Not: na ilgili yıla ilişkin verilerden birine ulaşılamadığını göstermektedir. Endeks değerinin 1'den büyük olması rekabet gücünün yüksek olduğunu göstermektedir.

\subsection{Brezilya'nın Yaş Meyve ve Sebze Sektörü Dış Ticaret Yapısının Analizi}

Tablo 3'de Brezilya'nın yaş meyve ve sebze sektöründe endüstri içi ticaret seviyesi gösterilmiştir. Tablo 3'de görüldüğü üzere, Brezilya'nın yaş meyve ve sebze sektöründe endüstri içi ticaret seviyesinin yüksek olduğu sektörler arasında; 0574 (Elma), 0575 (Üzüm), 0579 (Kavun, karpuz, papaya, elma, armut, ayva ve diğer meyveler (taze)) ve 0548 (Manyot, şerbetçi otu, salep, ararot, keçiboynuzu, seker pancar1-kamışı vs.)) bulunmaktadır. Endüstri içi ticaretin düşük olduğu sektörler arasında ise; 0571 (Portakal ve Mandalina (taze/kurutulmuş)), 0572 (Greyfurt, pomelo, limon ve diğer turunçgiller), 0573 (Muz), 0576 (incir (taze / kurutulmuş), 0541 (Patates (taze-soğutulmuş), 0542 (Baklagiller), 0544 (domates (taze/ dondurulmuş), 0545 (Taze ve Soğutulmuş Sebzeler), 0546 (Pişirilmiş ve Dondurulmuş Sebzeler) ve 0547 (Sebze ve sebze karışımları (geçici konserve edilmiş)) bulunmaktadır. Genel itibariyle değerlendirildiğinde Brezilya'nın yaş meyve ve sebze sektöründe endüstri içi ticaret seviyesinin düşük olduğu görülmektedir. 
Tablo 3. Yaş Meyve ve Sebze Sektöründe Endüstri içi Ticaretin Ölçümü

\begin{tabular}{|c|c|c|c|c|c|c|c|c|c|c|c|c|c|c|c|}
\hline Sektör & $\mathbf{2 0 0 0}$ & $\mathbf{2 0 0 1}$ & $\mathbf{2 0 0 2}$ & $\mathbf{2 0 0 3}$ & $\mathbf{2 0 0 4}$ & $\mathbf{2 0 0 5}$ & $\mathbf{2 0 0 6}$ & $\mathbf{2 0 0 7}$ & $\mathbf{2 0 0 8}$ & $\mathbf{2 0 0 9}$ & $\mathbf{2 0 1 0}$ & $\mathbf{2 0 1 1}$ & $\mathbf{2 0 1 2}$ & $\mathbf{2 0 1 3}$ & $\mathbf{2 0 1 4}$ \\
\hline $\mathbf{0 5 7 1}$ & 0,06 & 0,03 & 0,09 & 0,05 & 0,02 & 0,14 & 0,09 & 0,16 & 0,12 & 0,33 & $0,60^{*}$ & $0,93^{*}$ & $0,79^{*}$ & $0,68^{*}$ & $0,56^{*}$ \\
\hline $\mathbf{0 5 7 2}$ & 0,05 & 0,04 & 0,03 & 0,01 & 0,01 & 0,01 & 0,01 & 0,02 & 0,01 & 0,04 & 0,06 & 0,06 & 0,07 & 0,08 & 0,07 \\
\hline $\mathbf{0 5 7 3}$ & 0,00 & 0,00 & 0,00 & 0,00 & 0,00 & 0,00 & 0,00 & 0,00 & 0,00 & 0,00 & 0,00 & 0,00 & 0,00 & 0,00 & 0,00 \\
\hline $\mathbf{0 5 7 4}$ & $0,81^{*}$ & $0,76^{*}$ & $0,72^{*}$ & $0,58^{*}$ & 0,39 & $0,79^{*}$ & $0,87^{*}$ & $0,76^{*}$ & $0,74^{*}$ & $0,90^{*}$ & $0,95^{*}$ & $0,59^{*}$ & $0,88^{*}$ & $0,79^{*}$ & 0,44 \\
\hline $\mathbf{0 5 7 5}$ & $0,73^{*}$ & $0,91^{*}$ & $0,67^{*}$ & 0,47 & $0,60^{*}$ & 0,37 & 0,46 & 0,37 & 0,45 & $0,65^{*}$ & $0,77^{*}$ & $0,86^{*}$ & $0,95^{*}$ & $0,93^{*}$ & $0,73^{*}$ \\
\hline $\mathbf{0 5 7 6}$ & $0,83^{*}$ & $0,65^{*}$ & 0,46 & 0,32 & 0,33 & 0,41 & 0,37 & 0,45 & 0,41 & 0,46 & $0,64^{*}$ & 0,50 & 0,40 & 0,35 & $0,51^{*}$ \\
\hline $\mathbf{0 5 7 7}$ & 0,32 & 0,37 & 0,29 & 0,23 & 0,26 & 0,34 & 0,40 & 0,38 & $0,55^{*}$ & 0,42 & $0,53^{*}$ & $0,78^{*}$ & $0,90^{*}$ & $0,95^{*}$ & $0,87^{*}$ \\
\hline $\mathbf{0 5 7 9}$ & $0,93^{*}$ & $0,87^{*}$ & 0,73 & $0,51^{*}$ & $0,61^{*}$ & $0,67^{*}$ & $0,79^{*}$ & $0,77^{*}$ & $0,74^{*}$ & $0,90^{*}$ & $0,99^{*}$ & $0,93^{*}$ & $0,90^{*}$ & $0,97^{*}$ & $0,98^{*}$ \\
\hline $\mathbf{0 5 4 1}$ & 0,01 & 0,02 & 0,19 & 0,04 & 0,00 & 0,03 & 0,00 & $0,99^{*}$ & 0,09 & 0,38 & 0,03 & 0,25 & 0,05 & 0,13 & $0,59^{*}$ \\
\hline $\mathbf{0 5 4 2}$ & 0,12 & 0,04 & 0,39 & 0,07 & 0,06 & 0,05 & 0,23 & 0,44 & 0,02 & 0,37 & 0,05 & 0,19 & 0,21 & 0,13 & 0,45 \\
\hline $\mathbf{0 5 4 4}$ & 0,01 & 0,00 & 0,01 & 0,01 & $0,79^{*}$ & 0,22 & $0,65^{*}$ & $n a$ & 0,01 & $0,83^{*}$ & 0,23 & 0,12 & 0,15 & $0,94^{*}$ & 0,19 \\
\hline $\mathbf{0 5 4 5}$ & 0,18 & 0,18 & 0,08 & 0,08 & 0,07 & 0,07 & 0,06 & 0,19 & 0,05 & 0,02 & 0,01 & 0,03 & 0,00 & 0,01 & 0,02 \\
\hline $\mathbf{0 5 4 6}$ & 0,08 & 0,06 & 0,09 & 0,06 & 0,03 & 0,03 & 0,02 & 0,04 & 0,02 & 0,01 & 0,01 & 0,00 & 0,00 & 0,00 & 0,00 \\
\hline $\mathbf{0 5 4 7}$ & 0,00 & 0,00 & 0,01 & 0,06 & 0,02 & 0,05 & 0,01 & $0,61^{*}$ & 0,36 & 0,14 & 0,21 & 0,17 & 0,15 & 0,10 & 0,13 \\
\hline $\mathbf{0 5 4 8}$ & $0,63^{*}$ & 0,47 & $0,64^{*}$ & $0,67^{*}$ & $0,72^{*}$ & $0,81^{*}$ & $0,72^{*}$ & $0,88^{*}$ & $0,65^{*}$ & $0,73^{*}$ & $0,51^{*}$ & 0,45 & 0,40 & 0,42 & 0,38 \\
\hline
\end{tabular}

Kaynak: UN Comtrade veri tabanından yola çıkılarak tarafımızca hesaplanarak düzenlenmiştir. Not: Literatürde endeks değeri 0,50 'den yüksek ise endüstri-içi ticaretin olduğu kabul edilmektedir. * endüstri-içi ticaretin olduğunu göstermektedir. na ilgili yıla ilişkin verilerden birine ulaşılamadığını göstermektedir.

Tablo 4'de Açıklanmış Karşılaştırmalı Üstünlükler Endeks değerleri yer almaktadır. Brezilya'nın yaş meyve ve sebze sektöründe rekabet gücünün yüksek olduğu sektörler arasında; 0572 (Greyfurt, pomelo, limon ve diğer turunçgiller), 0575 (Üzüm), 0576 (incir (taze / kurutulmuş) bulunmaktadır. 0574 (Elma), 0577 (Çeşitli cevizler ve diğer kabuklu meyveler (taze/kurutulmuş)), 0579 (Kavun, karpuz, papaya, elma, armut, ayva ve diğer meyveler (taze)) sektörlerinde ise rekabet gücünün son yıllarda azaldığı görülmektedir. Genel itibariyle değerlendirildiğinde Brezilya'nın bazı yaş meyve sektöründe rekabet gücü olmasına rağmen yaş sebze sektöründe rekabet gücünün olmadığı görülmektedir. 
Tablo 4. Yaş Meyve ve Sebze Sektöründe Rekabet Gücünün Ölçümü

\begin{tabular}{|c|c|c|c|c|c|c|c|c|c|c|c|c|c|c|c|}
\hline Sektör & $\mathbf{2 0 0 0}$ & $\mathbf{2 0 0 1}$ & $\mathbf{2 0 0 2}$ & $\mathbf{2 0 0 3}$ & $\mathbf{2 0 0 4}$ & $\mathbf{2 0 0 5}$ & $\mathbf{2 0 0 6}$ & $\mathbf{2 0 0 7}$ & $\mathbf{2 0 0 8}$ & $\mathbf{2 0 0 9}$ & $\mathbf{2 0 1 0}$ & $\mathbf{2 0 1 1}$ & $\mathbf{2 0 1 2}$ & $\mathbf{2 0 1 3}$ & $\mathbf{2 0 1 4}$ \\
\hline $\mathbf{0 5 7 1}$ & 0,72 & 1,04 & 0,43 & 0,44 & 0,56 & 0,25 & 0,36 & 0,31 & 0,26 & 0,15 & 0,16 & 0,13 & 0,08 & 0,08 & 0,07 \\
\hline $\mathbf{0 5 7 2}$ & 044 & 0,67 & 0,82 & 1,14 & 1,03 & 1,24 & 1,50 & 1,48 & 1,30 & 1,37 & 1,31 & 1,54 & 1,46 & 1,62 & 2,03 \\
\hline $\mathbf{0 5 7 3}$ & 0,33 & 0,40 & 0,81 & 0,63 & 0,49 & 0,49 & 0,53 & 0,53 & 0,36 & 0,39 & 0,42 & 0,30 & 0,29 & 0,27 & 0,25 \\
\hline $\mathbf{0 5 7 4}$ & 1,53 & 0,77 & 1,17 & 1,11 & 1,73 & 1,01 & 0,61 & 1,04 & 1,01 & 0,81 & 0,65 & 0,35 & 0,49 & 0,58 & 0,34 \\
\hline $\mathbf{0 5 7 5}$ & 0,53 & 0,73 & 1,16 & 1,60 & 1,15 & 1,81 & 1,97 & 2,47 & 1,88 & 1,29 & 1,31 & 1,08 & 1,02 & 0,82 & 0,56 \\
\hline $\mathbf{0 5 7 6}$ & 1,22 & 1,20 & 1,36 & 1,41 & 1,62 & 1,44 & 1,61 & 2,07 & 1,70 & 1,99 & 1,01 & 1,49 & 1,79 & 1,53 & 1,55 \\
\hline $\mathbf{0 5 7 7}$ & 4,92 & 3,04 & 2,72 & 2,79 & 2,73 & 2,00 & 1,89 & 2,21 & 1,60 & 1,81 & 1,33 & 0,96 & 0,87 & 0,59 & 0,46 \\
\hline $\mathbf{0 5 7 9}$ & 1,21 & 1,42 & 1,37 & 1,55 & 1,28 & 1,22 & 1,20 & 1,29 & 1,28 & 1,12 & 0,96 & 0,88 & 0,86 & 0,89 & 1,02 \\
\hline $\mathbf{0 5 4 1}$ & 0,00 & 0,00 & 0,01 & 0,00 & 0,00 & 0,00 & 0,00 & 0,06 & 0,00 & 0,03 & 0,00 & 0,01 & 0,00 & 0,01 & 0,06 \\
\hline $\mathbf{0 5 4 2}$ & 0,10 & 0,06 & 0,34 & 0,06 & 0,04 & 0,04 & 0,12 & 0,38 & 0,04 & 0,27 & 0,04 & 0,18 & 0,30 & 0,21 & 0,40 \\
\hline $\mathbf{0 5 4 4}$ & 0,20 & 0,10 & 0,02 & 0,01 & 0,00 & 0,00 & 0,00 & 0,03 & 0,00 & 0,00 & 0,00 & 0,00 & 0,00 & 0,00 & 0,00 \\
\hline $\mathbf{0 5 4 5}$ & 0,08 & 0,07 & 0,02 & 0,02 & 0,01 & 0,02 & 0,01 & 0,06 & 0,01 & 0,00 & 0,00 & 0,01 & 0,00 & 0,00 & 0,00 \\
\hline $\mathbf{0 5 4 6}$ & 0,01 & 0,00 & 0,00 & 0,00 & 0,00 & 0,00 & 0,00 & 0,00 & 0,00 & 0,00 & 0,00 & 0,00 & 0,00 & 0,00 & 0,00 \\
\hline $\mathbf{0 5 4 7}$ & 0,04 & 0,04 & 0,06 & 0,23 & 0,13 & 0,09 & 0,00 & 0,33 & 0,20 & 0,12 & 0,27 & 0,24 & 0,22 & 0,19 & 0,26 \\
\hline
\end{tabular}

Kaynak: UN Comtrade veri tabanından yola çıkılarak tarafımızca hesaplanarak düzenlenmiştir. Not: Endeks değerinin 1'den büyük olması rekabet gücünün yüksek olduğunu göstermektedir.

\subsection{Rusya'nın Yaş Meyve ve Sebze Sektörü Dış Ticaret Yapısının Analizi}

Tablo 5'de Rusya'nın yaş meyve ve sebze sektöründe endüstri içi ticaret seviyesi gösterilmiştir. Tablo 5'de görüldüğü üzere, Rusya'da 0577 (Çeşitli cevizler ve diğer kabuklu meyveler (taze/kurutulmuş)), 0542 (Baklagiller) ve 0547 (Sebze ve sebze karışımları (geçici konserve edilmiş)) sektörlerinde bazı dönemlerde endüstri içi ticaretin yüksek olduğu görülmektedir. 0571 (Portakal ve Mandalina (taze/kurutulmuş)), 0572 (Greyfurt, pomelo, limon ve diğer turunçgiller), 0573 (Muz), 0574 (Elma), 0575 (Üzüm), 0576 (incir (taze / kurutulmuş), 0579 (Kavun, karpuz, papaya, elma, armut, ayva ve diğer meyveler (taze)), 0541 (Patates (taze-soğutulmuş), 0544 (domates (taze/ dondurulmuş), 0545 (Taze ve Soğutulmuş Sebzeler), 0546 (Pişirilmiş ve Dondurulmuş Sebzeler) ve 0548 (Manyot, şerbetçi otu, salep, ararot, keçiboynuzu, seker pancarı-kamışı vs.)) sektörlerinde endüstri içi ticaret seviyesinin düşük olduğu görülmektedir. Genel itibariyle değerlendirildiğinde, Rusya'nın yaş meyve ve sebze sektöründe endüstri içi ticaret seviyesinin düşük olduğu görülmektedir. Diğer bir ifadeyle Rusya yaş meyve ve sebze sektöründe ticaretini endüstriler arası ticaret şeklinde gerçekleştirmektedir. 
Tablo 5. Yaş Meyve ve Sebze Sektöründe Endüstri içi Ticaretin Ölçümü

\begin{tabular}{|c|c|c|c|c|c|c|c|c|c|c|c|c|c|c|c|}
\hline Sektör & $\mathbf{2 0 0 0}$ & $\mathbf{2 0 0 1}$ & $\mathbf{2 0 0 2}$ & $\mathbf{2 0 0 3}$ & $\mathbf{2 0 0 4}$ & $\mathbf{2 0 0 5}$ & $\mathbf{2 0 0 6}$ & $\mathbf{2 0 0 7}$ & $\mathbf{2 0 0 8}$ & $\mathbf{2 0 0 9}$ & $\mathbf{2 0 1 0}$ & $\mathbf{2 0 1 1}$ & $\mathbf{2 0 1 2}$ & $\mathbf{2 0 1 3}$ & $\mathbf{2 0 1 4}$ \\
\hline $\mathbf{0 5 7 1}$ & 0,01 & 0,01 & 0,02 & 0,04 & 0,02 & 0,02 & 0,02 & 0,03 & 0,02 & 0,01 & 0,00 & 0,00 & 0,00 & 0,00 & 0,00 \\
\hline $\mathbf{0 5 7 2}$ & 0,02 & 0,03 & 0,04 & 0,08 & 0,04 & 0,03 & 0,03 & 0,06 & 0,05 & 0,03 & 0,00 & 0,00 & 0,00 & 0,00 & 0,00 \\
\hline $\mathbf{0 5 7 3}$ & 0,01 & 0,02 & 0,03 & 0,06 & 0,03 & 0,02 & 0,02 & 0,04 & 0,03 & 0,02 & 0,00 & 0,00 & 0,07 & 0,06 & 0,05 \\
\hline $\mathbf{0 5 7 4}$ & 0,00 & 0,01 & 0,00 & 0,00 & 0,00 & 0,01 & 0,01 & 0,01 & 0,00 & 0,00 & 0,00 & 0,00 & 0,00 & 0,00 & 0,00 \\
\hline $\mathbf{0 5 7 5}$ & 0,00 & 0,00 & 0,00 & 0,00 & 0,00 & 0,00 & 0,00 & 0,00 & 0,00 & 0,00 & 0,00 & 0,00 & 0,00 & 0,00 & 0,00 \\
\hline $\mathbf{0 5 7 6}$ & 0,00 & 0,00 & 0,00 & 0,00 & 0,00 & 0,00 & 0,04 & 0,03 & 0,00 & 0,00 & 0,00 & 0,00 & 0,00 & 0,00 & 0,00 \\
\hline $\mathbf{0 5 7 7}$ & $0,84^{*}$ & $0,85^{*}$ & $0,51^{*}$ & $0,82^{*}$ & $0,98^{*}$ & 0,50 & 0,17 & 0,11 & 0,01 & 0,08 & 0,03 & 0,01 & 0,09 & 0,02 & 0,07 \\
\hline $\mathbf{0 5 7 9}$ & 0,09 & 0,10 & 0,06 & 0,08 & 0,07 & 0,03 & 0,03 & 0,01 & 0,01 & 0,00 & 0,00 & 0,00 & 0,00 & 0,00 & 0,01 \\
\hline $\mathbf{0 5 4 1}$ & 0,05 & 0,24 & 0,07 & 0,05 & 0,13 & 0,07 & 0,18 & 0,28 & 0,06 & 0,13 & 0,04 & 0,02 & 0,05 & 0,08 & 0,03 \\
\hline $\mathbf{0 5 4 2}$ & 0,20 & 0,41 & 0,40 & $0,82^{*}$ & $0,81^{*}$ & $0,83^{*}$ & $0,90^{*}$ & $0,96^{*}$ & $0,98^{*}$ & $0,58^{*}$ & $0,94^{*}$ & 0,31 & 0,18 & 0,34 & 0,37 \\
\hline $\mathbf{0 5 4 4}$ & 0,00 & 0,00 & 0,00 & 0,00 & 0,00 & 0,00 & 0,00 & 0,00 & 0,00 & 0,00 & 0,00 & 0,00 & 0,00 & 0,00 & 0,00 \\
\hline $\mathbf{0 5 4 5}$ & 0,16 & 0,13 & 0,04 & 0,12 & 0,14 & 0,10 & 0,10 & 0,04 & 0,07 & 0,04 & 0,02 & 0,03 & 0,02 & 0,05 & 0,02 \\
\hline $\mathbf{0 5 4 6}$ & 0,02 & 0,21 & 0,14 & 0,20 & 0,36 & 0,29 & 0,25 & 0,20 & 0,13 & 0,09 & 0,03 & 0,09 & 0,10 & 0,08 & 0,06 \\
\hline $\mathbf{0 5 4 7}$ & 0,41 & 0,05 & 0,16 & 0,20 & 0,18 & $0,63^{*}$ & $0,82^{*}$ & $0,56^{*}$ & $0,94^{*}$ & $0,74^{*}$ & $0,61^{*}$ & $0,77^{*}$ & $0,63^{*}$ & $0,68^{*}$ & 0,24 \\
\hline $\mathbf{0 5 4 8}$ & 0,22 & 0,19 & 0,12 & 0,08 & 0,05 & 0,06 & 0,01 & 0,03 & 0,00 & 0,02 & 0,00 & 0,01 & 0,02 & 0,02 & 0,01 \\
\hline
\end{tabular}

Kaynak: UN Comtrade veri tabanından yola çıkılarak tarafımızca hesaplanarak düzenlenmiştir. Not: Literatürde endeks değeri 0,50 'den yüksek ise endüstri-içi ticaretin olduğu kabul edilmektedir. * endüstri-içi ticaretin olduğunu göstermektedir.

Tablo 6'da Rusya'nın yaş meyve ve sebze sektöründe Açıklanmış Karşılaştırmalı Üstünlükler Endeks değerleri yer almaktadır. Analiz sonuçlarından da görüldügüü üzere Rusya'nın yaş meyve ve sebze sektöründe AKÜ endeks değeri 1'den küçüktür. Diğer bir ifadeyle Rusya’nın yaş meyve ve sebze sektöründe rekabet gücü düşüktür. 
Tablo 6. Yaş Meyve ve Sebze Sektöründe Rekabet Gücünün Ölçümü

\begin{tabular}{|c|c|c|c|c|c|c|c|c|c|c|c|c|c|c|c|}
\hline Sektör & $\mathbf{2 0 0 0}$ & $\mathbf{2 0 0 1}$ & $\mathbf{2 0 0 2}$ & $\mathbf{2 0 0 3}$ & $\mathbf{2 0 0 4}$ & $\mathbf{2 0 0 5}$ & $\mathbf{2 0 0 6}$ & $\mathbf{2 0 0 7}$ & $\mathbf{2 0 0 8}$ & $\mathbf{2 0 0 9}$ & $\mathbf{2 0 1 0}$ & $\mathbf{2 0 1 1}$ & $\mathbf{2 0 1 2}$ & $\mathbf{2 0 1 3}$ & $\mathbf{2 0 1 4}$ \\
\hline $\mathbf{0 5 7 1}$ & 0,01 & 0,02 & 0,03 & 0,06 & 0,03 & 0,03 & 0,04 & 0,07 & 0,04 & 0,02 & 0,00 & 0,00 & 0,00 & 0,01 & 0,01 \\
\hline $\mathbf{0 5 7 2}$ & 0,02 & 0,03 & 0,05 & 0,10 & 0,06 & 0,04 & 0,05 & 0,10 & 0,05 & 0,06 & 0,00 & 0,00 & 0,00 & 0,00 & 0,00 \\
\hline $\mathbf{0 5 7 3}$ & 0,02 & 0,02 & 0,05 & 0,10 & 0,06 & 0,04 & 0,04 & 0,07 & 0,05 & 0,03 & 0,00 & 0,00 & 0,13 & 0,12 & 0,09 \\
\hline $\mathbf{0 5 7 4}$ & 0,01 & 0,01 & 0,01 & 0,01 & 0,00 & 0,01 & 0,01 & 0,01 & 0,01 & 0,01 & 0,00 & 0,00 & 0,00 & 0,00 & 0,00 \\
\hline $\mathbf{0 5 7 5}$ & 0,00 & 0,00 & 0,00 & 0,00 & 0,00 & 0,00 & 0,00 & 0,00 & 0,00 & 0,00 & 0,00 & 0,00 & 0,00 & 0,00 & 0,00 \\
\hline $\mathbf{0 5 7 6}$ & 0,00 & 0,00 & 0,00 & 0,00 & 0,00 & 0,00 & 0,00 & 0,00 & 0,00 & 0,00 & 0,00 & 0,00 & 0,00 & 0,00 & 0,00 \\
\hline $\mathbf{0 5 7 7}$ & 0,19 & 0,28 & 0,10 & 0,16 & 0,22 & 0,08 & 0,07 & 0,06 & 0,00 & 0,04 & 0,01 & 0,00 & 0,04 & 0,00 & 0,01 \\
\hline $\mathbf{0 5 7 9}$ & 0,05 & 0,06 & 0,04 & 0,05 & 0,06 & 0,03 & 0,03 & 0,01 & 0,01 & 0,01 & 0,00 & 0,00 & 0,00 & 0,00 & 0,00 \\
\hline $\mathbf{0 5 4 1}$ & 0,06 & 0,08 & 0,04 & 0,07 & 0,05 & 0,07 & 0,14 & 0,20 & 0,07 & 0,13 & 0,06 & 0,05 & 0,06 & 0,07 & 0,06 \\
\hline $\mathbf{0 5 4 2}$ & 0,05 & 0,10 & 0,41 & 0,24 & 0,24 & 0,20 & 0,19 & 0,11 & 0,14 & 0,44 & 0,20 & 0,92 & 1,22 & 0,74 & 0,84 \\
\hline $\mathbf{0 5 4 4}$ & 0,00 & 0,00 & 0,00 & 0,00 & 0,00 & 0,00 & 0,00 & 0,00 & 0,00 & 0,00 & 0,00 & 0,00 & 0,00 & 0,00 & 0,00 \\
\hline $\mathbf{0 5 4 5}$ & 0,06 & 0,03 & 0,01 & 0,05 & 0,06 & 0,04 & 0,05 & 0,03 & 0,04 & 0,03 & 0,01 & 0,02 & 0,02 & 0,04 & 0,02 \\
\hline $\mathbf{0 5 4 6}$ & 0,02 & 0,04 & 0,03 & 0,05 & 0,09 & 0,09 & 0,07 & 0,05 & 0,03 & 0,03 & 0,01 & 0,03 & 0,02 & 0,02 & 0,02 \\
\hline $\mathbf{0 5 4 7}$ & 0,51 & 0,37 & 0,46 & 0,73 & 0,74 & 0,57 & 0,45 & 0,41 & 0,29 & 0,32 & 0,18 & 0,23 & 0,25 & 0,26 & 0,14 \\
\hline $\mathbf{0 5 4 8}$ & 0,12 & 0,11 & 0,07 & 0,05 & 0,02 & 0,01 & 0,00 & 0,01 & 0,00 & 0,00 & 0,00 & 0,00 & 0,00 & 0,00 & 0,00 \\
\hline
\end{tabular}

Kaynak: UN Comtrade veri tabanından yola çıkılarak tarafımızca hesaplanarak düzenlenmiştir. Not: Endeks değerinin 1'den büyük olması rekabet gücünün yüksek olduğunu göstermektedir.

\subsection{Hindistan'ın Yaş Meyve ve Sebze Sektörü Dış Ticaret Yapısının Analizi}

Tablo 7'de Hindistan'ın yaş meyve ve sebze sektöründe endüstri içi ticaret seviyesi gösterilmiştir. Tablo 7'de görüldügü üzere, 0577 (Çeşitli cevizler ve diğer kabuklu meyveler (taze/kurutulmuş)), 0579 (Kavun, karpuz, papaya, elma, armut, ayva ve diğer meyveler (taze)) ve 0548 (Manyot, şerbetçi otu, salep, ararot, keçiboynuzu, seker pancarı-kamışı vs.)) sektörlerinde endüstri içi ticaret seviyesinin yüksek olduğu görülmektedir. 0571 (Portakal ve Mandalina (taze/kurutulmuş)), 0574 (Elma), 0575 (Üzüm) sektörlerinde ise endüstri içi ticaretin bazı dönemlerde yüksek olduğu görülmektedir. 0572 (Greyfurt, pomelo, limon ve diğer turunçgiller), 0573 (Muz), 0576 (incir (taze/kurutulmuş), 0541 (Patates (tazesoğutulmuş), 0542 (Baklagiller), 0544 (domates (taze/ dondurulmuş), 0545 (Taze ve Soğutulmuş Sebzeler), 0546 (Pişirilmiş ve Dondurulmuş Sebzeler) ve 0547 (Sebze ve sebze karışımları (geçici konserve edilmiş)) sektörlerinde ise endüstri içi ticaret seviyesinin düşük olduğu görülmektedir. Genel itibariyle değerlendirildiğinde Hindistan'ın yaş meyve ve sebze sektöründe endüstri içi ticaret seviyesi düşüktür. Diğer bir ifadeyle yaş meyve ve sebze sektöründe Hindistan'ın ticareti endüstriler arası ticaret şeklindedir. 
Tablo 7. Yaş Meyve ve Sebze Sektöründe Endüstri içi Ticaretin Ölçümü

\begin{tabular}{|c|c|c|c|c|c|c|c|c|c|c|c|c|c|c|c|}
\hline Sektör & $\mathbf{2 0 0 0}$ & $\mathbf{2 0 0 1}$ & $\mathbf{2 0 0 2}$ & $\mathbf{2 0 0 3}$ & $\mathbf{2 0 0 4}$ & $\mathbf{2 0 0 5}$ & $\mathbf{2 0 0 6}$ & $\mathbf{2 0 0 7}$ & $\mathbf{2 0 0 8}$ & $\mathbf{2 0 0 9}$ & $\mathbf{2 0 1 0}$ & $\mathbf{2 0 1 1}$ & $\mathbf{2 0 1 2}$ & $\mathbf{2 0 1 3}$ & $\mathbf{2 0 1 4}$ \\
\hline $\mathbf{0 5 7 1}$ & 0,02 & 0,04 & 0,07 & 0,05 & 0,07 & 0,19 & 0,31 & $0,56^{*}$ & $0,84^{*}$ & $0,84^{*}$ & $0,62^{*}$ & $0,79^{*}$ & $0,73^{*}$ & $0,62^{*}$ & 0,32 \\
\hline $\mathbf{0 5 7 2}$ & 0,02 & 0,00 & 0,03 & 0,00 & 0,00 & 0,00 & 0,00 & 0,01 & 0,00 & 0,00 & 0,00 & 0,00 & 0,01 & 0,01 & 0,00 \\
\hline $\mathbf{0 5 7 3}$ & na & na & 0,00 & na & na & na & 0,00 & na & Na & 0,00 & na & 0,00 & na & na & 0,00 \\
\hline $\mathbf{0 5 7 4}$ & $0,57^{*}$ & 0,08 & $0,59^{*}$ & 0,23 & $0,83^{*}$ & $0,53^{*}$ & 0,50 & 0,25 & 0,31 & 0,15 & 0,19 & 0,14 & 0,10 & 0,12 & 0,04 \\
\hline $\mathbf{0 5 7 5}$ & $0,83^{*}$ & $0,85^{*}$ & $0,55^{*}$ & 0,45 & $0,84^{*}$ & 0,39 & 0,47 & 0,44 & 0,34 & 0,32 & 0,32 & 0,32 & 0,22 & 0,30 & 0,35 \\
\hline $\mathbf{0 5 7 6}$ & 0,03 & 0,08 & 0,00 & 0,06 & 0,01 & 0,00 & 0,01 & 0,00 & 0,00 & 0,00 & 0,00 & 0,00 & 0,00 & 0,01 & 0,00 \\
\hline $\mathbf{0 5 7 7}$ & $0,86^{*}$ & $0,59^{*}$ & $0,80^{*}$ & $0,98^{*}$ & $0,99^{*}$ & $0,98^{*}$ & $0,95^{*}$ & $0,94^{*}$ & $0,86^{*}$ & $0,85^{*}$ & $0,78^{*}$ & $0,74^{*}$ & $0,74^{*}$ & $0,80^{*}$ & $0,68^{*}$ \\
\hline $\mathbf{0 5 7 9}$ & $0,81^{*}$ & $0,80^{*}$ & $0,97^{*}$ & $0,59^{*}$ & $0,59^{*}$ & $0,63^{*}$ & $0,60^{*}$ & $0,61^{*}$ & $0,56^{*}$ & $0,63^{*}$ & $0,70^{*}$ & $0,76^{*}$ & $0,73^{*}$ & $0,86^{*}$ & $0,92^{*}$ \\
\hline $\mathbf{0 5 4 1}$ & 0,07 & 0,01 & na & 0,07 & 0,13 & 0,11 & 0,00 & 0,00 & 0,00 & na & na & na & na & na & na \\
\hline $\mathbf{0 5 4 2}$ & 0,87 & 0,25 & 0,21 & 0,22 & 0,35 & $0,58^{*}$ & 0,38 & 0,20 & 0,12 & 0,07 & 0,18 & 0,21 & 0,15 & 0,26 & 0,14 \\
\hline $\mathbf{0 5 4 4}$ & na & na & na & na & 0,03 & 0,02 & 0,00 & 0,00 & 0,00 & 0,00 & 0,00 & 0,00 & 0,00 & 0,00 & 0,00 \\
\hline $\mathbf{0 5 4 5}$ & 0,06 & 0,27 & 0,29 & 0,09 & 0,05 & 0,06 & 0,00 & 0,01 & 0,00 & 0,00 & 0,01 & 0,02 & 0,00 & 0,01 & 0,00 \\
\hline $\mathbf{0 5 4 6}$ & 0,00 & 0,01 & 0,02 & 0,06 & 0,01 & 0,08 & 0,03 & 0,04 & 0,05 & 0,06 & 0,01 & 0,02 & 0,02 & 0,01 & 0,00 \\
\hline $\mathbf{0 5 4 7}$ & 0,00 & 0,01 & 0,00 & 0,00 & 0,00 & 0,01 & 0,01 & 0,02 & 0,01 & 0,01 & 0,04 & 0,07 & 0,06 & 0,08 & 0,05 \\
\hline $\mathbf{0 5 4 8}$ & $0,80^{*}$ & $0,51^{*}$ & $0,87^{*}$ & $0,89^{*}$ & $0,92^{*}$ & $0,74^{*}$ & $0,57^{*}$ & $0,58^{*}$ & $0,72^{*}$ & $0,76^{*}$ & $083^{*}$ & $0,90^{*}$ & $0,86^{*}$ & $0,86^{*}$ & $0,55^{*}$ \\
\hline
\end{tabular}

Kaynak: UN Comtrade veri tabanından yola çıkılarak tarafımızca hesaplanarak düzenlenmiştir. Not: Literatürde endeks değeri 0,50 'den yüksek ise endüstri-içi ticaretin olduğu kabul edilmektedir. * endüstri-içi ticaretin olduğunu göstermektedir. na ilgili yıla ilişkin verilerden birine ulaşılamadığını göstermektedir.

Tablo 8'de Hindistan'ın yaş meyve ve sebze sektöründe Açıklanmış Karşılaştırmalı Üstünlükler Endeks değerleri yer almaktadır. Hindistan'ın yaş meyve ve sebze sektöründe rekabet gücünün yüksek olduğu sektörler arasında; 0577 (Çeşitli cevizler ve diğer kabuklu meyveler (taze/kurutulmuş)), 0542 (Baklagiller), 0545 (Taze ve Soğutulmuş Sebzeler), 0547 (Sebze ve sebze karışımları (geçici konserve edilmiş)) bulunmaktadır. Bu sektörlerde AKÜ endeks değeri 1'den büyüktür. Ele alınan diğer sektörlerde ise rekabet gücünün düşük olduğu görülmektedir. Genel itibariyle değerlendirildiğinde Hindistan'ın yaş meyve ve sebze sektöründe rekabet gücünün düşük olduğu görülmektedir. 
Tablo 8. Yaş Meyve ve Sebze Sektöründe Rekabet Gücü Ölçümü

\begin{tabular}{|c|c|c|c|c|c|c|c|c|c|c|c|c|c|c|c|}
\hline Sektör & $\mathbf{2 0 0 0}$ & $\mathbf{2 0 0 1}$ & $\mathbf{2 0 0 2}$ & $\mathbf{2 0 0 3}$ & $\mathbf{2 0 0 4}$ & $\mathbf{2 0 0 5}$ & $\mathbf{2 0 0 6}$ & $\mathbf{2 0 0 7}$ & $\mathbf{2 0 0 8}$ & $\mathbf{2 0 0 9}$ & $\mathbf{2 0 1 0}$ & $\mathbf{2 0 1 1}$ & $\mathbf{2 0 1 2}$ & $\mathbf{2 0 1 3}$ & $\mathbf{2 0 1 4}$ \\
\hline $\mathbf{0 5 7 1}$ & 0,24 & 0,25 & 0,19 & 0,25 & 0,21 & 0,14 & 0,16 & 0,09 & 0,06 & 0,04 & 0,03 & 0,08 & 0,08 & 0,04 & 0,03 \\
\hline $\mathbf{0 5 7 2}$ & 0,17 & 0,16 & 0,11 & 0,21 & 0,39 & 0,21 & 0,32 & 0,25 & 0,32 & 0,27 & 0,24 & 0,20 & 0,20 & 0,18 & 0,18 \\
\hline $\mathbf{0 5 7 3}$ & 0,14 & 0,10 & 0,07 & 0,06 & 0,07 & 0,08 & 0,07 & 0,06 & 0,12 & 0,18 & 0,20 & 0,11 & 0,16 & 0,11 & 0,19 \\
\hline $\mathbf{0 5 7 4}$ & 0,08 & 0,01 & 0,24 & 0,06 & 0,21 & 0,20 & 0,17 & 0,12 & 0,16 & 0,08 & 0,13 & 0,12 & 0,08 & 0,09 & 0,04 \\
\hline $\mathbf{0 5 7 5}$ & 0,63 & 0,54 & 0,74 & 0,80 & 0,55 & 0,87 & 1,02 & 0,96 & 1,14 & 0,96 & 0,93 & 0,60 & 1,30 & 1,36 & 1,47 \\
\hline $\mathbf{0 5 7 6}$ & 0,05 & 0,11 & 0,00 & 0,04 & 0,02 & 0,00 & 0,05 & 0,03 & 0,01 & 0,01 & 0,01 & 0,02 & 0,01 & 0,05 & 0,01 \\
\hline $\mathbf{0 5 7 7}$ & 16 & 13,8 & 12,2 & 8,17 & 8,41 & 6,76 & 5,88 & 5,47 & 5,75 & 3,98 & 3,01 & 3,25 & 2,89 & 2,78 & 2,48 \\
\hline $\mathbf{0 5 7 9}$ & 0,61 & 0,54 & 0,47 & 0,96 & 1,04 & 0,95 & 1,12 & 0,99 & 1,03 & 0,85 & 0,82 & 0,64 & 0,55 & 0,52 & 0,53 \\
\hline $\mathbf{0 5 4 1}$ & 0,30 & 0,12 & 0,11 & 0,47 & 0,35 & 0,52 & 0,40 & 0,37 & 0,72 & 0,31 & 0,53 & 0,47 & 0,33 & 0,39 & 1,5 \\
\hline $\mathbf{0 5 4 2}$ & 6,85 & 4,21 & 3,87 & 3,56 & 4,30 & 7,38 & 5,45 & 2,88 & 1,41 & 0,86 & 1,69 & 1,74 & 1,40 & 2,24 & 1,32 \\
\hline $\mathbf{0 5 4 4}$ & 0,01 & 0,01 & 0,08 & 0,03 & 0,04 & 0,01 & 0,14 & 0,28 & 0,42 & 0,30 & 0,20 & 0,59 & 0,40 & 0,42 & 0,57 \\
\hline $\mathbf{0 5 4 5}$ & 1,37 & 1,42 & 1,43 & 1,46 & 1,59 & 1,17 & 1,51 & 1,48 & 1,56 & 1,77 & 1,50 & 1,05 & 1,01 & 1,31 & 0,92 \\
\hline $\mathbf{0 5 4 6}$ & 0,54 & 0,55 & 0,53 & 0,52 & 0,52 & 0,38 & 0,29 & 0,27 & 0,30 & 0,19 & 0,27 & 0,34 & 0,25 & 0,36 & 0,43 \\
\hline $\mathbf{0 5 4 7}$ & 7,51 & 6,85 & 7,37 & 6,56 & 7,45 & 10,7 & 10,1 & 6,61 & 8,23 & 8,59 & 4,67 & 4,37 & 5,01 & 3,88 & 5,57 \\
\hline $\mathbf{0 5 4 8}$ & 0,11 & 0,04 & 0,09 & 0,15 & 0,08 & 0,07 & 0,83 & 0,07 & 0,09 & 0,08 & 0,07 & 0,06 & 0,05 & 0,09 & 0,10 \\
\hline
\end{tabular}

Kaynak: UN Comtrade veri tabanından yola çıkılarak tarafımızca hesaplanarak düzenlenmiştir. Not: Endeks değerinin 1'den büyük olması rekabet gücünün yüksek olduğunu göstermektedir.

\section{5. Çin'in Yaş Meyve ve Sebze Sektörü Dış Ticaret Yapısının Analizi}

Tablo 9'da Çin'in yaş meyve ve sebze sektöründe endüstri içi ticaret seviyesi gösterilmiştir. Tablo 9'da görüldüğü üzere, 0577 (Çeşitli cevizler ve diğer kabuklu meyveler (taze/kurutulmuş)), 0579 (Kavun, karpuz, papaya, elma, armut, ayva ve diğer meyveler (taze)) ve 0548 (Manyot, şerbetçi otu, salep, ararot, keçiboynuzu, seker pancar1-kamışı vs.)) sektörlerinde endüstri içi ticaret seviyesi yüksektir. 0571 (Portakal ve Mandalina (taze/kurutulmuş)), 0572 (Greyfurt, pomelo, limon ve diğer turunçgiller), 0575 (Üzüm), 0576 (incir (taze / kurutulmuş) ve 0542 (Baklagiller) sektörlerinde bazı dönemlerde endüstri içi ticaret seviyesinin yüksek olduğu görülmektedir. 0573 (Muz), 0574 (Elma), 0541 (Patates (taze-soğutulmuş), 0544 (domates (taze/ dondurulmuş), 0545 (Taze ve Soğutulmuş Sebzeler), 0546 (Pişirilmiş ve Dondurulmuş Sebzeler), 0547 (Sebze ve sebze karışımları (geçici konserve edilmiş)) sektörlerinde ise endüstri içi ticaret seviyesinin düşük olduğu görülmektedir. Genel itibariyle değerlendirildiğinde Çin'in yaş meyve ve sebze sektöründe endüstri içi ticaret seviyesinin düşük olduğu görülmektedir. Diğer bir ifadeyle Çin yaş meyve ve sebze sektöründe endüstriler arası ticaret yapmaktadır. 
Tablo 9. Yaş Meyve ve Sebze Sektöründe Endüstri içi Ticaretin Ölçümü

\begin{tabular}{|c|c|c|c|c|c|c|c|c|c|c|c|c|c|c|c|}
\hline Sektör & 2000 & 2001 & 2002 & 2003 & 2004 & 2005 & 2006 & 2007 & 2008 & 2009 & 2010 & 2011 & 2012 & 2013 & 2014 \\
\hline 0571 & $0,70^{*}$ & $0,86^{*}$ & $0,65^{*}$ & $0,76^{*}$ & $0,59^{*}$ & 0,45 & $0,51^{*}$ & 0,37 & 0,27 & 0,20 & 0,28 & 0,32 & 0,25 & 0,22 & 0,23 \\
\hline 0572 & $0,60^{*}$ & $0,87^{*}$ & $0,83^{*}$ & $0,90^{*}$ & $0,97^{*}$ & $0,62^{*}$ & 0,43 & 0,26 & 0,22 & 0,30 & 0,31 & 0,40 & 0,34 & 0,37 & $0,78^{*}$ \\
\hline 0573 & 0,03 & 0,08 & 0,13 & 0,13 & 0,12 & 0,13 & 0,11 & 0,11 & 0,09 & 0,07 & 0,04 & 0,03 & 0,03 & 0,04 & 0,01 \\
\hline 0574 & 0,21 & 0,29 & 0,26 & 0,20 & 0,19 & 0,15 & 0,12 & 0,12 & 0,12 & 0,13 & 0,16 & 0,22 & 0,17 & 0,12 & 0,08 \\
\hline 0575 & 0,06 & 0,09 & 0,34 & 0,49 & 0,47 & 0,48 & $0,73^{*}$ & $0,92^{*}$ & $0,90^{*}$ & $0,88^{*}$ & $0,90^{*}$ & $0,84^{*}$ & $0,88^{*}$ & $0,77^{*}$ & $0,80^{*}$ \\
\hline 0576 & 0,12 & 0,09 & 0,17 & 0,20 & 0,18 & 0,30 & $0,67^{*}$ & $0,77^{*}$ & $0,84^{*}$ & 0,13 & 0,07 & 0,01 & 0,08 & 0,08 & 0,15 \\
\hline 0577 & 0,32 & $0,59^{*}$ & $0,62^{*}$ & $0,73^{*}$ & $0,76^{*}$ & $0,66^{*}$ & $0,64^{*}$ & $0,83^{*}$ & $0,87^{*}$ & $0,85^{*}$ & $0,76^{*}$ & $0,83^{*}$ & $0,85^{*}$ & $0,98^{*}$ & $0,84^{*}$ \\
\hline 0579 & $0,90^{*}$ & $0,76^{*}$ & $0,85^{*}$ & $0,93^{*}$ & $0,87^{*}$ & $0,91^{*}$ & $0,96^{*}$ & $0,87^{*}$ & $0,84^{*}$ & $0,70^{*}$ & $0,68^{*}$ & $0,59^{*}$ & $0,52^{*}$ & $0,52^{*}$ & $0,51^{*}$ \\
\hline 0541 & 0,17 & 0,01 & 0,00 & 0,00 & 0,00 & 0,00 & 0,00 & 0,00 & 0,00 & 0,00 & 0,00 & 0,00 & 0,00 & 0,00 & 0,00 \\
\hline 0542 & 0,23 & 0,22 & 0,16 & 0,11 & 0,16 & 0,31 & 0,39 & 0,33 & 0,33 & 0,28 & 0,49 & $0,59^{*}$ & $0,72^{*}$ & $0,80^{*}$ & $0,71^{*}$ \\
\hline 0544 & 0,00 & na & 0,00 & na & na & 0,00 & na & 0,00 & 0,00 & $\mathrm{Na}$ & na & 0,00 & na & na & na \\
\hline 0545 & 0,01 & 0,00 & 0,00 & 0,00 & 0,00 & 0,00 & 0,00 & 0,00 & 0,00 & 0,00 & 0,00 & 0,00 & 0,00 & 0,00 & 0,00 \\
\hline 0546 & 0,13 & 0,07 & 0,07 & 0,10 & 0,09 & 0,07 & 0,06 & 0,06 & 0,04 & 0,03 & 0,04 & 0,04 & 0,05 & 0,04 & 0,04 \\
\hline 0547 & 0,00 & 0,00 & 0,01 & 0,02 & 0,02 & 0,04 & 0,02 & 0,02 & 0,02 & 0,03 & 0,04 & 0,03 & 0,03 & 0,03 & 0,02 \\
\hline 0548 & 0,40 & $0,95^{*}$ & $0,92^{*}$ & $0,99^{*}$ & $0,81^{*}$ & $0,81^{*}$ & $0,66^{*}$ & $0,69^{*}$ & $0,98^{*}$ & $0,70^{*}$ & $0,61^{*}$ & $0,56^{*}$ & 0,43 & 0,49 & 0,50 \\
\hline
\end{tabular}

Kaynak: UN Comtrade veri tabanından yola çıkılarak tarafımızca hesaplanarak düzenlenmiştir. Not: Literatürde endeks değeri 0,50 'den yüksek ise endüstri-içi ticaretin olduğu kabul edilmektedir. * endüstri-içi ticaretin olduğunu göstermektedir. na ilgili yıla ilişkin verilerden birine ulaşılamadığını göstermektedir.

Tablo 10'da Çin'in yaş meyve ve sebze sektöründe Açıklanmış Karşılaştırmalı Üstünlükler Endeks değerleri yer almaktadır. Çin'in yaş meyve ve sebze sektöründe rekabet gücünün yüksek olduğu sektörler arasında; 0546 (Pişirilmiş ve Dondurulmuş Sebzeler), 0547 (Sebze ve sebze karışımları (geçici konserve edilmiş)), 0548 (Manyot, şerbetçi otu, salep, ararot, keçiboynuzu, seker pancarı-kamış1 vs.)) bulunmaktadır. Bu sektörlerde AKÜ endeks değerinin 1'den büyük olduğu görülmektedir. Ele alınan diğer sektörlerde ise endeks değeri 1'den küçüktür diğer bir ifadeyle rekabet gücü düşüktür. Genel itibariyle değerlendirildiğinde Çin'in yaş meyve ve sebze sektöründe rekabet gücünün düşük olduğu görülmektedir. 
Tablo 10. Yaş Meyve ve Sebze Sektöründe Rekabet Gücünün Ölçümü

\begin{tabular}{|c|c|c|c|c|c|c|c|c|c|c|c|c|c|c|c|}
\hline Sektör & $\mathbf{2 0 0 0}$ & $\mathbf{2 0 0 1}$ & $\mathbf{2 0 0 2}$ & $\mathbf{2 0 0 3}$ & $\mathbf{2 0 0 4}$ & $\mathbf{2 0 0 5}$ & $\mathbf{2 0 0 6}$ & $\mathbf{2 0 0 7}$ & $\mathbf{2 0 0 8}$ & $\mathbf{2 0 0 9}$ & $\mathbf{2 0 1 0}$ & $\mathbf{2 0 1 1}$ & $\mathbf{2 0 1 2}$ & $\mathbf{2 0 1 3}$ & $\mathbf{2 0 1 4}$ \\
\hline $\mathbf{0 5 7 1}$ & 0,36 & 0,23 & 0,26 & 0,33 & 0,30 & 0,33 & 0,32 & 0,36 & 0,53 & 0,67 & 0,58 & 0,66 & 0,80 & 0,85 & 0,86 \\
\hline $\mathbf{0 5 7 2}$ & 0,03 & 0,08 & 0,06 & 0,08 & 0,06 & 0,10 & 0,15 & 0,23 & 0,27 & 0,34 & 0,30 & 0,28 & 0,38 & 0,39 & 0,29 \\
\hline $\mathbf{0 5 7 3}$ & 0,01 & 0,02 & 0,02 & 0,03 & 0,01 & 0,01 & 0,01 & 0,01 & 0,00 & 0,00 & 0,00 & 0,00 & 0,00 & 0,00 & 0,00 \\
\hline $\mathbf{0 5 7 4}$ & 1,06 & 0,93 & 1,03 & 1,29 & 1,07 & 1,05 & 1,02 & 1,02 & 1,20 & 1,31 & 1,22 & 1,20 & 1,15 & 1,05 & 1,05 \\
\hline $\mathbf{0 5 7 5}$ & 0,00 & 0,01 & 0,04 & 0,09 & 0,09 & 0,08 & 0,11 & 0,13 & 0,14 & 0,22 & 0,21 & 0,28 & 0,33 & 0,30 & 0,35 \\
\hline $\mathbf{0 5 7 6}$ & 0,02 & 0,00 & 0,01 & 0,00 & 0,00 & 1,03 & 0,01 & 0,01 & 0,00 & 0,00 & 0,00 & 0,00 & 0,00 & 0,00 & 0,00 \\
\hline $\mathbf{0 5 7 7}$ & 0,67 & 0,66 & 0,56 & 0,54 & 0,37 & 0,27 & 0,31 & 0,25 & 0,20 & 0,24 & 0,19 & 0,16 & 0,18 & 0,17 & 0,14 \\
\hline $\mathbf{0 5 7 9}$ & 0,24 & 0,21 & 0,23 & 0,27 & 0,21 & 0,19 & 0,19 & 0,17 & 0,18 & 0,21 & 0,20 & 0,21 & 0,22 & 0,23 & 0,23 \\
\hline $\mathbf{0 5 4 1}$ & 0,09 & 0,14 & 0,16 & 0,25 & 0,21 & 0,31 & 0,29 & 0,26 & 0,27 & 0,37 & 0,27 & 0,34 & 0,32 & 0,22 & 0,50 \\
\hline $\mathbf{0 5 4 2}$ & 2,41 & 2,38 & 2,44 & 2,93 & 1,78 & 1,56 & 1,34 & 1,31 & 1,45 & 1,31 & 1,02 & 1,14 & 1,05 & 0,96 & 0,66 \\
\hline $\mathbf{0 5 4 4}$ & 0,02 & 0,03 & 0,04 & 0,05 & 0,04 & 0,04 & 0,04 & 0,04 & 0,06 & 0,05 & 0,05 & 0,06 & 0,08 & 0,07 & 0,10 \\
\hline $\mathbf{0 5 4 5}$ & 1,18 & 1,17 & 1,20 & 1,31 & 0,99 & 0,98 & 1,03 & 0,83 & 0,66 & 0,89 & 1,27 & 1,25 & 0,97 & 0,84 & 0,87 \\
\hline $\mathbf{0 5 4 6}$ & 3,39 & 3,28 & 2,30 & 2,17 & 1,73 & 1,68 & 1,69 & 1,52 & 1,47 & 1,35 & 1,47 & 1,54 & 1,43 & 1,26 & 1,21 \\
\hline $\mathbf{0 5 4 7}$ & 11,1 & 9,34 & 7,76 & 8,29 & 6,12 & 3,41 & 4,66 & 3,71 & 3,72 & 2,86 & 3,15 & 3,16 & 2,85 & 2,51 & 2,16 \\
\hline $\mathbf{0 5 4 8}$ & 3,87 & 3,42 & 3,69 & 3,88 & 2,54 & 2,63 & 2,22 & 1,86 & 1,94 & 2,01 & 2,01 & 1,46 & 1,32 & 1,43 & 1,45 \\
\hline
\end{tabular}

Kaynak: UN Comtrade veri tabanından yola çıkılarak tarafımızca hesaplanarak düzenlenmiştir. Not: Endeks değerinin 1'den büyük olması rekabet gücünün yüksek olduğunu göstermektedir.

\section{Sonuç}

Türkiye ve BRIC ülkelerinin yaş meyve ve sebze sektörünün dış ticaret yapısının analiz edildiği bu çalışmada, iki uygulama yapılmıştır. Öncelikle yaş meyve ve sebze sektöründe gerçekleştirilen ticaretin endüstri içi ticaret şeklinde mi yoksa endüstriler arası ticaret şeklinde mi gerçekleştirildiği araştırılmıştır. Daha sonra sektörün rekabet gücü analiz edilmiștir. Endüstri içi ticaretin ölçümünde Grubel-Lloyd Endeksi kullanılırken; rekabet gücü ölçümünde Balassa tarafından geliştirilen Açıklanmış Karşılaştırmalı Üstünlükler Endeksi kullanılmıştır. Analiz sonucunda elde edilen bulgular Türkiye'nin ve BRIC ülkelerinin yaş meyve ve sebze sektöründe endüstri içi ticaret seviyesinin düşük olduğunu göstermiştir. Diğer bir ifadeyle ticaret endüstriler arası ticaret şeklinde gerçekleşmektedir. Yani Türkiye ve BRIC ülkelerinde endüstri içi ticaret düzeyinin düşük olması karşılaştırmalı üstünlükler teorisinin geçerliliğini büyük ölçüde devam ettirmesini ifade etmektedir. Rekabet gücü ölçüm sonucunda ise Türkiye'nin yaş meyve ve sebze sektöründe rekabet gücünün yüksek olduğu görülmüştür. Buna karş1lık BRIC ülkelerinin yaş meyve ve sebze sektöründe rekabet gücü düşük bulunmuştur.

Türkiye'nin yaş meyve ve sebze sektöründe rekabet gücünün yüksek olmasını etkileyen en önemli faktörler arasında; tarım politikalarının etkinleștirilmesiyle birlikte tarım sektöründe artan verimlilik ve ihracat potansiyeli ve yaş meyve ve sebze sektöründe artan kalite bulunmaktadır. Türkiye'nin yaş meyve ve sebze sektöründe rekabet gücünü artırarak sürdürebilmesi için pazar talebine uygun çeşitlerin, uygun miktarlarda, kalitede ve pazar talebini karş1layacak düzeyde ve organize olmuş bir şekilde üretiminin gerçekleştirilmesi gerekmektedir. Gelecek yıllarda şiddetini artırması beklenen kuraklık sorunu dikkate alınarak gerekli önlemlerin alınması gerekmektedir. Ayrıca ürünlerde hormon kullanımı azaltılarak organik tarım teşvik edilmelidir. Tarım ürünlerinin kalitesinin artırılmasında tarım 
kesiminde çalışan nüfusun yeterli bilgi ve beceriye sahip olması amaciyla eğitimin ve niteliğinin artırılması gerekmektedir. Sektörün ihracatının artırılmasında diğer bir unsurda pazarlamadır. Ambalajlama, paketleme ve marka dış pazarlarda talebi artıracaktır. $\mathrm{Bu}$ nedenle ihracatçıların bilgilendirilerek teşvik edilmesi ve kalite sistemlerinin yaygınlaştırılması son derecede önemlidir. 


\section{KAYNAKÇA}

BAKHSHINEZAJ, M., ZADEH, A. (2012). Comparative Advantage of Selected Agriculture Products in Iran: A Revealed Comparative Advantage Assessment. World Applied Sciences Journal, 19 (10), 1449-1452.

ÇAKMAK, Ö. (2006). Türkiye ile Almanya, İtalya, Fransa ve İngiltere Arasında İmalat Endüstrisinde Endüstri-içi Ticaretin Yapısı: 1991-2004. Ekonomik ve Sosyal Araştırmalar Dergisi, 2(1), 30-47.

DEVİREN, N., KARATAŞ, M. (2007). Türkiye İle Çin Halk Cumhuriyeti Arasındaki Endüstri-içi Ticaret. İktisat İşletme ve Finans Dergisi, 22, 16-31.

DOAKA (2015). TR 63 Bölgesi Yaş Sebze Meyve Sektör Raporu. 1-40. http://www.dogaka.gov.tr/Icerik/Dosya/www.dogaka.gov.tr_621_FB8B45NT_Yas-

Sebze-Meyve-Sektor-Raporu-2015.pdf. (Erişim Tarihi: 06.06.2016)

ERKAN, B. (2012). Ülkelerin Karşılaştırmalı İhracat Performanslarının Açıklanmış Karşılaştırmalı Üstünlük Katsayılarıyla Belirlenmesi: Türkiye-Suriye Örneği. ZKÜ Sosyal Bilimler Dergisi, 8(15), 196-218.

ERKAN, B., ARPACI, B., YARALI, F., GÜVENÇ, İ. (2015). Türkiye'nin Sebze İhracatında Karş1laştırmalı Üstünlükleri. KSÜ Doğa Bil.Dergisi, 18(4), 70-76.

GRUBEL, H., LLOYD, P. (1975). Intra-Industry Trade: The Theory and Measurement of International Trade in Differentiated Products London: MacMillanPres.

HAN, K., LEE, J. (2012). FDI and Vertical Intra-Industry Trade Between Korea and China. Korea and the World Economy, 13(1), 115-139.

HASSAN, M. (2013). An Analysis of Competitiveness of Pakistan's Agricultural Export Commodities. Journal of Business and Management, 11(5), 29-34.

HELLVIN, L. (1996). Vertical Intra-Industry Trade Between China and OECD Countries. OECD Devolopment Centre Working Paper, 114, 6-35.

HU, X., MA, Y. (1999). International Intra-Industry Trade Of China. Weltwirtschaftliches Archiv Kiel Institute for World Economics, 135(1), 1-28.

ISHCHUKOVA, N., SMUTKA, L. (2013). Revealed Comparative Advantage of Russian Agricultural Exports. Acta Universitatis Agriculturae Et Silviculturae Mendelianae Brunensis, 4, 941-952.

LI, Y., DAI, L., HUANG, B. (2015). Analysis of the Influential Factors of Manufactured Products Intra-Industry Trade Between China-South Korea and China' Policy. Theoretical Economics Letters, 5, 114-124.

ÖZKAYA, H. (2010). Tekstil Sektöründe Endüstri-İçi Ticareti Etkileyen Faktörler Üzerine Ampirik Çalışma. Uşak Üniversitesi Sosyal Bilimler Dergisi, 3(2), 136-157.

SERIN, V., CIVAN, A. (2008). Revealed Comparative Advantage and Competitiveness: A Case Study for Turkey towards the EU. Journal of Economic and Social Research, $10(2), 25-41$

ŞUTSO (2013). Şanlıurfa Yaş Meyve ve Sebze Yetiştiriciliği İhtiyaç Analizi Raporu. 1-91. http://www.karacadag.org.tr/dosyalar2014/13-DFD- 
$\% 2020 \% 20 \%$ C5\%9EUTSO,\%20Sanliurfa_Yas_meyve_sebze_ihtiyac_analizi_raporu _15\%20temmuz.pdf (Erişim Tarihi: 08.06.2016).

T.C. EKONOMI BAKANLIĞI (2014). Yaş Meyve ve Sebze Sektörü. 1-12. http://gtb.org.tr/dosya/pdf/yas-meyve-sebze-sektor-raporu-1.pdf (Erişim Tarihi: 07.07.2016).

TÜRKEKUL, B., ABAY, C. (2009). Türkiye'de Ekonomik Krizler ve Tarıma Yansımaları. Küresel Kriz ve Tarım Çalıştayı İzmir, 1-38.

UN COMTRADE http://comtrade.un.org/. (Erişim Tarihi: 06.05.2016). 